1971-08-01

\title{
Space usage by the small mammal, Dipodomys microps (merriam)
}

Barney William Cornaby

Brigham Young University - Provo

Follow this and additional works at: https://scholarsarchive.byu.edu/etd

Part of the Life Sciences Commons

\section{BYU ScholarsArchive Citation}

Cornaby, Barney William, "Space usage by the small mammal, Dipodomys microps (merriam)" (1971). Theses and Dissertations. 7661.

https://scholarsarchive.byu.edu/etd/7661

This Thesis is brought to you for free and open access by BYU ScholarsArchive. It has been accepted for inclusion in Theses and Dissertations by an authorized administrator of BYU ScholarsArchive. For more information, please contact ellen_amatangelo@byu.edu. 
SPACE USAGE BY THE SMALL MAMMAL, DIPODOMYS MICROPS (MERRIAM)

\author{
A Thesis \\ Presented to the \\ Department of Zoology \\ Brigham Young University
}

\begin{abstract}
In Partial Fulfillment
of the Requirements for the Degree

Master of Science
\end{abstract}

by

Barney W. Cornaby

August 1971 


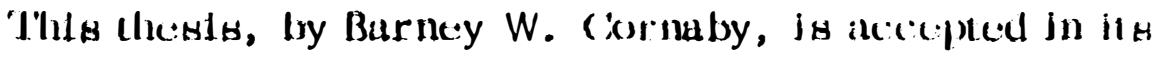
present form by the Department of Zoology of Brigham Young University as satisfying the thesis requirement for the degree of Master of Science. 


\section{ACKNOWLEDGMENTS}

I extend appreciation to the following people: Dr. Clive D. Jorgensen for suggesting the study and for his subsequent interest in and committment to my education during all phases of my graduate studies; Dr. Melvin W. Carter for constructive comments on procedures and analyses; Mr. Tyler H. Rogers for technical assistance in the circuitry of the activity arena; Mrs. Linda S. Cornaby, my wife, for clerical assistance in the field and laboratory; and my advisory committee who critically reviewed the manuscript.

Financial support came from a Brigham Young University research grant (115-77-580-00) and, in part, from a D Eldon Beck Scholarship. The Department of Zoology at Brigham Young University cooperated fully by making facilities and equipment readily available. 
TABLE OF CONTENTS

Page

ACKNOWLEDGMENTS ...................... iii

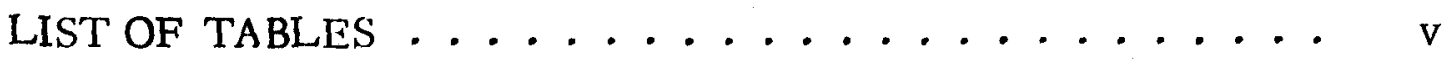

LIST OF ILLUSTRATIONS ................. vi

INTRODUCTION $\ldots \ldots \ldots \ldots \ldots \ldots$

MATERIALS AND METHODS . ............ 3

Experimental Animals ............. 3

Activity Arena .................. 3

Experimental Design ............. 3

Analyses ..................... 7

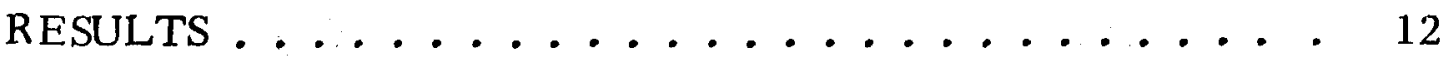

DISCUSSION AND CONCLUSIONS . . . . ........... 23

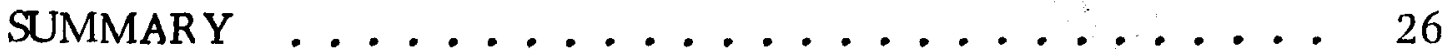

LITERATURE CITED ..................... 27

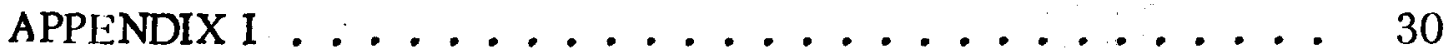

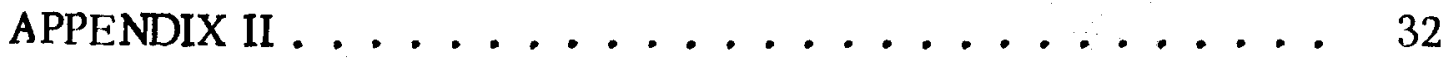




\section{LIST OF TABLES}

Table

1. Chi-square values for goodness of fit tests for gate usages by Dipodomys microps for ex

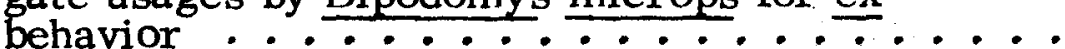

2. Chi-square values for goodness of fit tests for gate usages by Dipodomys microps for in

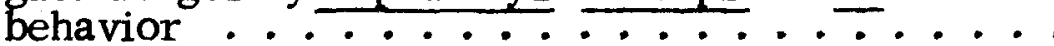

3. Chi-square values for goodness of fit tests for gate usages by Dipodomys microps for inter

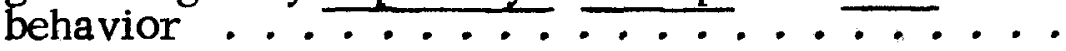

4. Total number of gate usages by Dipodomys microps

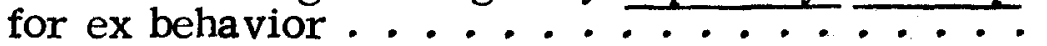

5. Total number of gate usages by Dipodomys microps

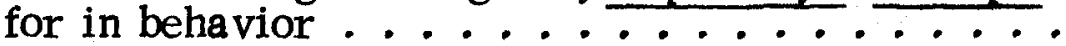

6. Total number of gate usages by Dipodomys microps for inter behavior .......... 20

7. Summary of multiple regression analyses of modified chi-square values from Tables $1-3 \ldots 21$

8. Summary of multiple regression analyses of modified chi-square values from Tables $4-6$. 22 


\section{LIST OF ILLUSTRATIONS}

Figure

1. Activity arena and event monitor used to record gate usage by Dipodomys microps ...... 5

2. Top and cross-sectional view of the gate

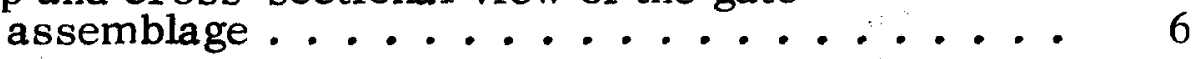

3. Schema of activity arena showing positions of corrals and gates ............... 


\section{INTRODUCTION}

The concept of home range is an important biological phenomenon and has received considerable attention. In applying the concept to mammals Burt (1943) defined it as, "that area traversed by the individual in its normal activities of food getting, mating, and caring for young." Later, Hayne (1949) defined a circular home range with concentric zones of variable utilization around a center of activity. Both workers emphasized the need to know the behavior patterns of the animals within their respective home ranges. The statistical evaluation initiated by Hayne (1949) has been refined to provide increasingly precise probability estimates of an animal being at any specified distance from its center of activity (Dice and Clark, 1953; Calhoun and Casby, 1958; Harrison, 1958; Burge, 1967). Recent research in social interactions of small mammal populations used the density probability function to estimate home ranges (Jorgensen, 1968a, 1968b; Speth, 1969).

The above studies mea sure the activity ranges of nocturnal rodents by induction from data obtained with capture-recapture trapping techniques, and typically, these methods ignore the movement patterns to and from the center of activity (Calhoun and Casby, 1958).

A priori, an animal would be expected to establish and use recognizable, predictable, non-random patterns of activity in space. Yet the aforementioned studies of small mammal home ranges often assumed that animals used the area randomly within each intensity of use zone. Although this assumption seems biologically unrealistic, 
ecologists and mammalogists have continued to refine methods of statistically measuring small mammal activity in the field while simultaneously neglecting the fundamental behavior patterns of the animals and thus jeopardizing the soundness of their interpretations (Brown, 1966).

The supposed patterns of use within an home range could be influenced by several variables. Among them are the presence of predators and the availability and location of food, mates, and cover. A quantitative investigation of the randomness or non-randomness of movement behavior as affected by these variables is needed to confirm the probability data of carlier studies.

The purpose of this rescarch is to determine how the Grcat Basin kangaroo rat, Dipodomys microps (Merriam) (Durrant, 1952; Miller and Kellogg, 1955), utilizes space when influenced by random and non-random food distributions. It will also contribute information leading to a more reliable statistical basis for the interpretation of data obtained during future research concerning population parameters of small mammals that require knowledge of home range. 


\section{MATERIALS AND METHODS}

\section{Experimental Animals}

Adult kangaroo rats were live-trapped ten kilometers west of Jerico, Juab County, Utah in the summer and fall of 1969. Each was weighed and sexed prior to its retention in a temperature controlled $\left(21^{\circ} \mathrm{C}\right)$ laboratory. Diet consisted of whole wheat, whole millet, and cracked corn given daily; with dried alfalfa, fresh carrots, and water provided periodically.

Activity Arena

An activity arena, $2.44 \mathrm{~m} \times 1.22 \mathrm{~m} \times 0.12 \mathrm{~m}$, was constructed of plywood and the interior painted gray with epoxy concrete enamel (Fig. 1). This simulated home range was partitioned by wire-mesh fences into three concentric corrals with a nesting can provided in the center area. Each end of the arena had a separate enclosure provided. A ceiling of plexiglas perforated with numbered, equidistant holes rested flush with the top of the wire fences. When an animal moved through any of the fourteen continuously monitored gates, it depressed the flexible metal pedal (Fig. 2) that completed a circuit and the animal's passage was recorded by a modified Brush Instruments Model RE 361000 operations monitor.

Experimental Design

Each full experiment included observations of one animal 
for 18 consecutive days (24-hour periods) and consisted of the following schedule:

Phase A. Conditioning phase with randomly scattered feed ............. 2 days

Phase B. Testing phase with two feeding schedules $\ldots \ldots \ldots . . . \ldots 16$ days

(1) Randomly scattered feed ... 4 days,

(2) One aggregate of feed .... 4 days,

(3) Randomly scattered feed ... 4 days,

(4) One aggregate of feed .... 4 days.

One kangaroo rat was tested under the alternate sequence of (2), (1), (4), and (3).

The daily weight of whole wheat and millet necessary to maintain constant body weight was determined for each experimental animal prior to being introduced into the activity arena. During the two randomly scattered feeding periods one seed of wheat or millet was dropped through holes in the ceiling, selected with the aid of a random numbers table (Ostle, 1964). Approximately 80 of the possible 1104 holes were randomly selected each day the feed was randomly scattered. During the four days of the first aggregate feeding, the total daily food was dropped through one hole. The number of this hole was selected randomly from those included in the outer enclosure (Fig. 1). During the second period of the aggregate feeding period a hole at the other end of the outer enclosure was arbitrarily selected. Feed was provided once daily at approximately 5:30 p. m. The room was brightly illuminated during the first 24 hours of the conditioning phase to encourage the animal to locate and use 


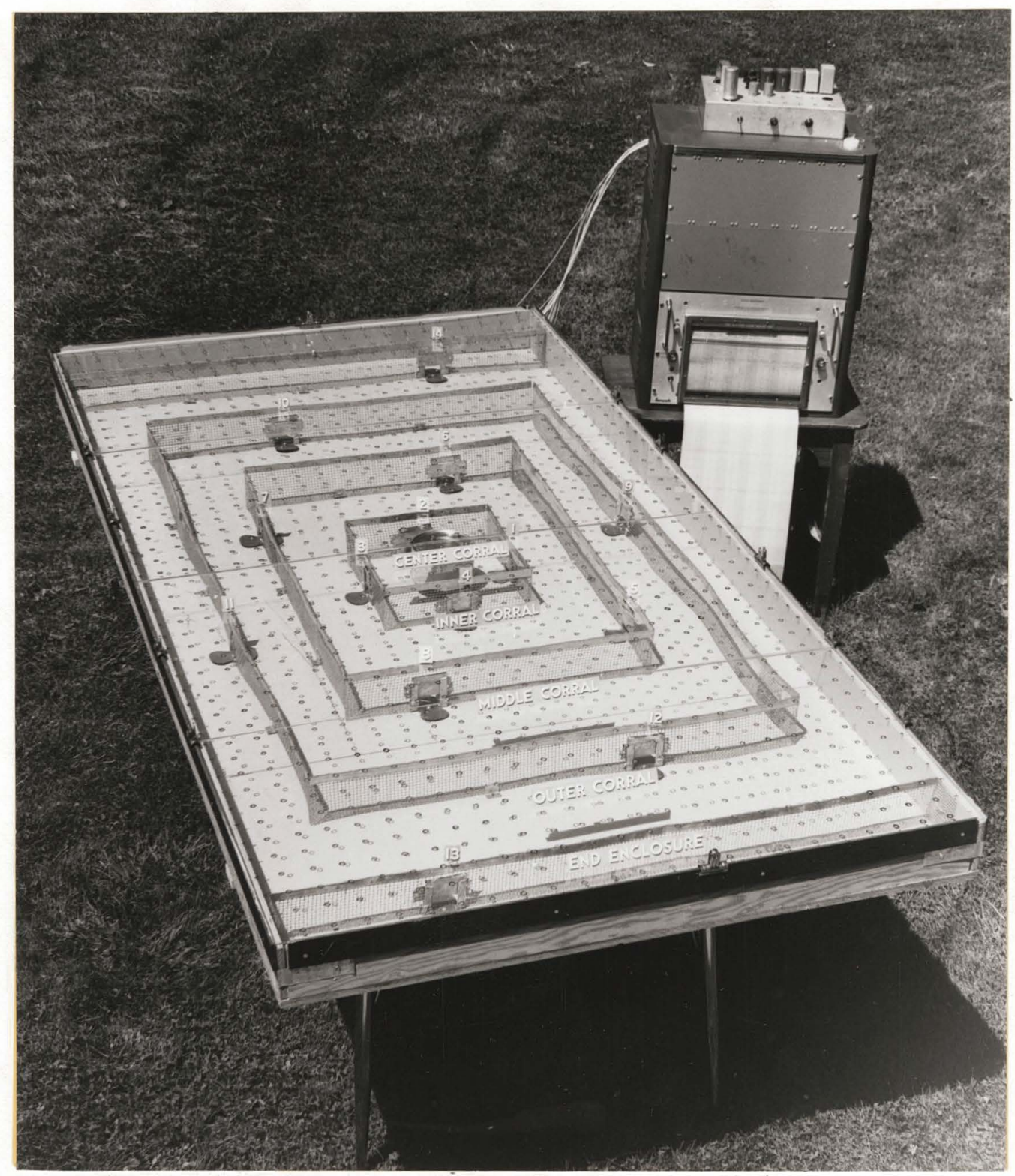

Fig. 1. Activity arena and event monitor used to record gate usage by Dipodomys microps. 


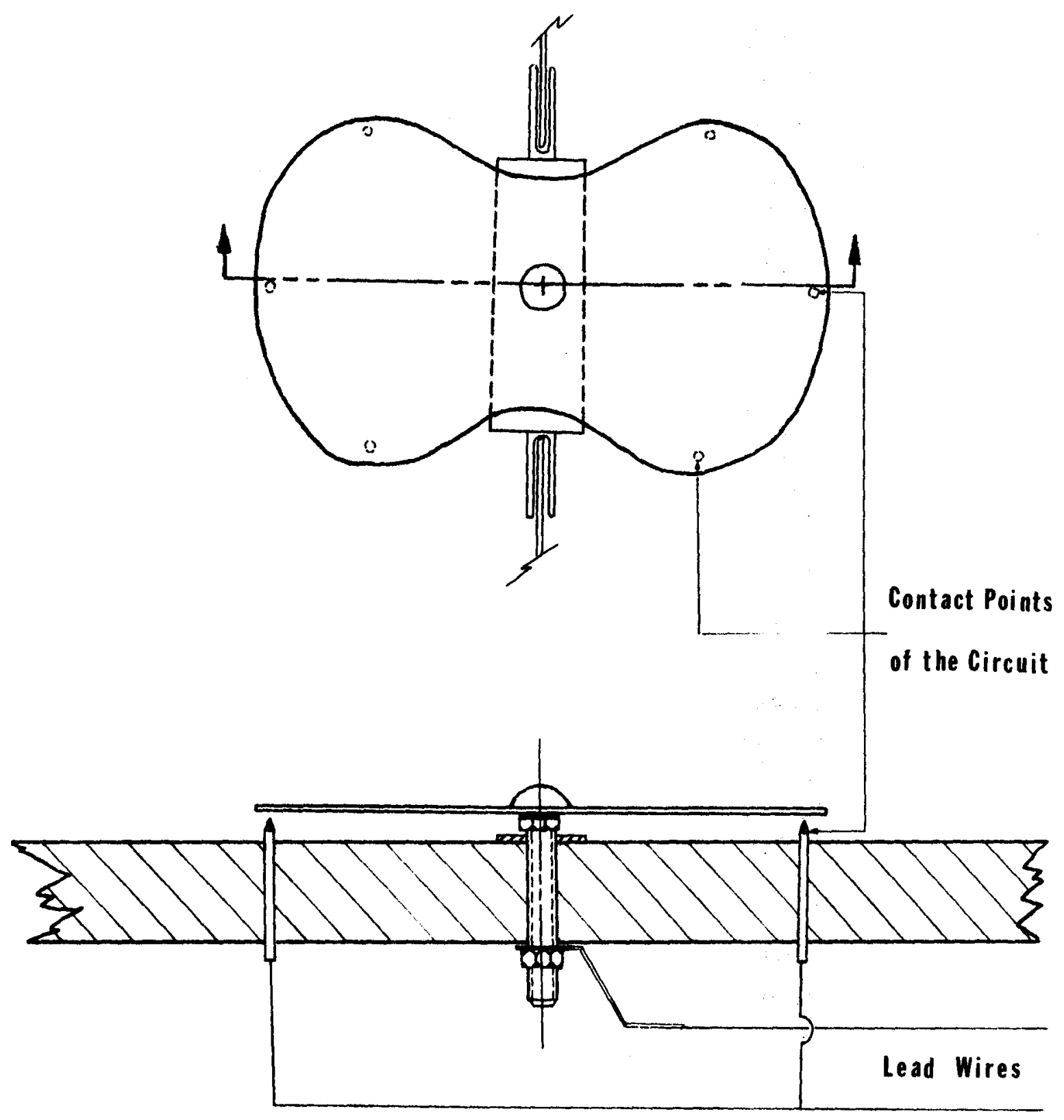

Fig. 2. Top and cross-sectional view of the gate assemblage. 
the darkened nesting can in the center of the arena. For the rcmaining 17 days the laboratory was dimly illuminated by a partially covered 15 watt bulb. After each full experiment the corrals were removed and the arena and gate pedals cleaned.

Analyses

Experimental animals did not have access to all gates at any one time since the arena was divided into concentric corrals that could be reached only by going through a connecting gate (Fig. 3). Animals in the center corral had access to gates 1, 2, 3, and 4; but once in the inner corral, they could use gates $5,6,7$, or 8 and move into the middle corral, or gates $1,2,3$, or 4 and return to the center corral. Either gates $9,10,11$, or 12 opening to the outer corral; or $5,6,7$, or 8 leading back to the inner corral were available from the middle corral. From the outer corral animals could return to the middle corral through gates $9,10,11$, or 12 ; or enter one of the two end enclosures through gates 13 or 14 .

Three kinds of movement behavior were assumed: (1) movement away from the nest can (ex), (2) movement toward the nest can (in), (3) movement free of association with the nest can (inter). These three are illustrated in the following example:

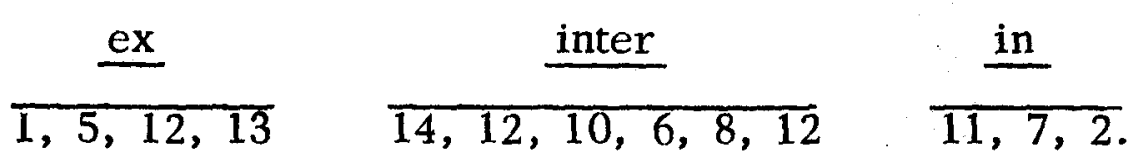

The number of times an animal used each of the 14 gates was tabulated for each four day experimental period. These values were grouped and totaled according to the following gate sets: $1-4,5-8$, 


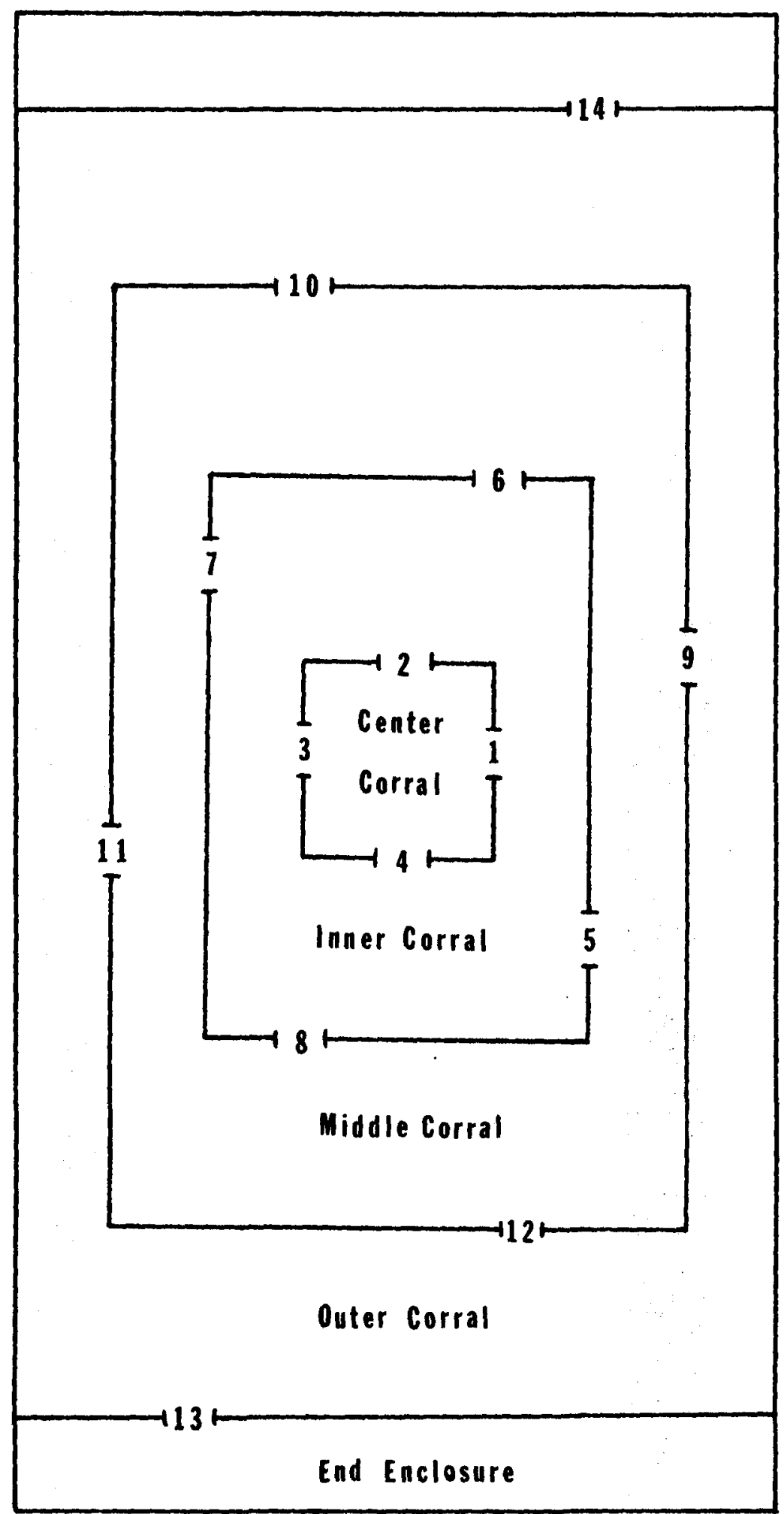

Fig. 3. Schema of activity arena showing positions of corrals and gates. 
$9-12$, and $13-14$

The expected usage $\left(\underline{E}_{\mathbf{k}}\right)$ of the $\mathrm{k}^{\text {th }}$ gate of the gate set $1-4$ for the ex bchavior was determined with $\underline{E}_{\underline{k}}=\left(\underline{f}_{\underline{k}}\right)\left(\left\langle\underline{g}_{k_{j}}\right)\right.$, where $\underline{f}_{k}$ is the relative frequency of usage (assigned as 0.25 for each gate) and $\underline{g}_{k j}$ is the total number of times gates $\underline{k}$ were used for that gate set during testing period $j$. Expected usage $\left(\underline{E}_{k j}\right)$ of gates $5-14$ for ex behavior and of gates $1-12$ for in behavior were determined with:

$$
\underline{E}_{k j}=\left[\sum\left(\frac{1 / \underline{d}_{i k}}{\sum 1 / d_{i k}}\right)\left(\frac{g_{i j}}{\xi g_{i j}}\right)\right]\left(\xi g_{k j}\right)
$$

where:

$$
\begin{aligned}
& \underline{E}_{\underline{k j}} \quad=\text { the expected usage of a given gate } \underline{k} \text { during a } \\
& \underline{\mathrm{d}}_{\mathrm{ik}} \quad=\text { the distance between gates where } \underline{\mathbf{i}} \text { represents } \\
& \text { the gate just left and } \underline{k} \text { represents the gate that } \\
& \text { was used next, } \\
& g_{i j}=\text { the number of times each gate was used where } \underline{i} \\
& \text { represents the various gates in the previously } \\
& \text { used gate set and where } \mathfrak{i} \text { represents a given } \\
& \text { feeding period, } \\
& \sum_{\underline{k}} g_{k j}=\text { the total number of times that gates were used } \\
& \text { where } \underline{\mathrm{k}} \text { represents the various gates in the gate } \\
& \text { set being used during a particular period } j \text {. }
\end{aligned}
$$

An example is prov lded that demonstrates the computations of $\underline{E}_{\underline{k}}$ and $\underline{E}_{\mathrm{kj}_{j}}$ using data from $\Delta$ : ex, experimental days 1 - 4 (Appendix II). Expected usage for gate 1 is $\underline{E}_{\underline{k}}=\left(\underline{f}_{k}\right)\left(\sum_{\varepsilon} g_{k j}\right)=(0.25)(37)=9.5$ gates which means that of 37 gate usages for the gate set $1-4$, gate 1 
would be expected to be used 9.5 times; expected usages for gates 2,3 , and 4 are also 9.5 and are determined the same way. In the inner corral the animal can use gate $5,6,7$, or 8 . Expected usage for gate 5 may be calculated where $\left(1 / \underline{d}_{i k}\right)\left(\sum_{i} 1 / d_{i k}\right)$ and $\underline{d}$ is $33.02 \mathrm{~cm}$ for gates 1 to $5,45.09 \mathrm{~cm}$ for 1 to $6,6 \overline{6.04} \mathrm{~cm}$ for 1 to 7 , and 60.03 $\mathrm{cm}$ for 1 to 8 (A ppendix I): thus $(1 / 33.02) /[(1 / 33.02)+(1 / 45.09)+$ $(1 / 66.04)+(1 / 60.33)]=0.360$. Similar computations obtain $\left(1 / \underline{\mathrm{d}}_{\mathrm{ik}}\right)\left(\sum_{i} 1 / \underline{\mathrm{d}}_{\mathrm{ik}}\right)$ for gates 2 to $5,6,7$, and $8 ; 3$ to $5,6,7$, and 8 ; and 4 to $5,6,7$, and 8 . These values are $0.174,0.183$, and 0.348 for gates 2,3 , and 4 , respectively. Observed frequency is $g_{i j} / \leqslant g_{i j}$ where $g_{i j}$ is 4 for gate 1 and $\sum_{i j} g_{i j}$ is 37 , thus $4 / 37=0.108$. For gate $2 g_{i j} / \sum g_{i j}=10 / 37=0.567$, with 0.216 and 0.108 for gates 3 and 4 ,

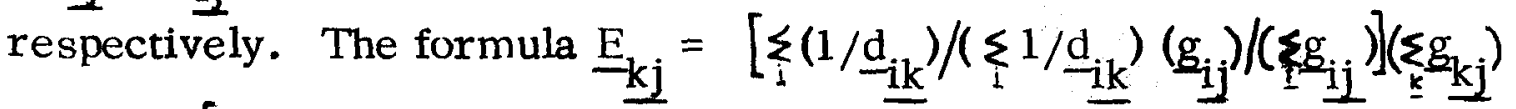
becomes $[(0.343)(0.108)+(\overrightarrow{0.174)}(0.567)+(0.18 \overline{3})(0.216)+$ $(0.348)(0.108)](30)=6.44$ expected gate usages, which means that based on inter-gate distances and weighted by the pattern of gate usage observed in the previously used gate set, gate 5 would be expected to be used 6.43 times of 30 gate usages for the gate set $5-8$. Expected gate usages for gates 6,7 , and 8 are $8.35,9.32$, and 5.87, respectively. To obtain $E_{k j}$ for gates $9,10,11$, and 12 and then, in turn, for 13 and 14 , etc., this procedure is repeated.

Movement of animals during inter behavior was apparently non-directional and required still different analyses. Gates $1-8$ were accessible from the inner corral but the use of gates $1-4$ would qualify this part of the sequences as in behavior, so only gates $5-8$ were considered. All the gates in the rest of the arena were considered for inter behavior, i. e., gates $5-12$ from the middle corral 
and gates $9-14$ from the outer corral (Fig. 3). Expected usage $\left(\underline{E}_{\underline{k}}\right)$ was estimated with $\underline{E}_{\underline{k}}=\left(\underline{f}_{\underline{k}}\right)\left(\underline{\xi}_{\underline{i j}}\right)$ where $\underline{f}_{\underline{k}}$ is the relative frequency of usage with 0.250 assigned to each of the four gates in the inner corral, 0.125 to each of the eight gates in the middle corral, and 0.167 to each gate in the outer corral; and where $\sum_{i} g_{i j}$ is the total number of gates $\underline{\mathbf{i}}$ used per gate grouping during period $\mathfrak{j}$, e.g., $5-8,5-12,9-14$ (Appendix II).

The chi-square goodness of fit test (Ghent, 1967) was used to determine significant departures from the expected. 


\section{RESULTS}

The null hypothesis $\left(\underline{\mathrm{H}}_{\mathrm{O}}\right)$ of the random use of space was tested, by contrasting the calculated theoretical and the observed gate usages for each gate set, with the chi-square goodness of fit test. Chi-square values for each gate are presented (Appendix II) but only values for gate sets are shown in Tables $1-3$. Five percent was used as the significance level, thus only one rejection of 20 possible chi-square values was necessary to suggest that the kangaroo rats used the space non-randomly or preferentially. Thirty of forty chisquare values were rejected for ex behavior when the feed was scattered randomly. Also, 32 out of $40 \mathrm{chi}$-square values were too high when the feed was aggregated. During ex behavior the kangaroo rats apparently selected some gates in the arena more often than other gates, regardless of how the feed was distributed.

There were 23 rejections of $\underline{\mathrm{H}}_{\underline{\mathrm{O}}}$ out of 30 tests for in behavior (Table 2) when the feed was randomly scattered, and 22 when the feed was aggregated. Again, the animals apparently used the gates preferentially during both feeding distributions for in behavior.

The results for inter behavior (Table 3 ) show 19 rejections of $\underline{\mathrm{H}}_{\mathrm{O}}$ out of 60 chi-square tests for both feeding distributions combined with 11 for randomly scattered feed and 8 for aggregated feed. Since only one rejection out of 20 tests was necessary to reject randomness, it was concluded that the animals used gates nonrandomly during inter behavior also. 
Table 1. Chi-square values for goodness of fit tests for gate usages by Dipodomys microps for ex behavior during 16 days.

\begin{tabular}{|c|c|c|c|c|}
\hline \multirow{3}{*}{$\begin{array}{l}\text { Animals } \\
\text { and } \\
\text { Gate Sets }\end{array}$} & \multicolumn{4}{|c|}{ Chi-Square Values } \\
\hline & \multicolumn{2}{|c|}{$\begin{array}{l}\text { Days of Randomly } \\
\text { Scattered Feed }\end{array}$} & \multicolumn{2}{|c|}{$\begin{array}{c}\text { Days of } \\
\text { Aggregated Feed }\end{array}$} \\
\hline & $1-4$ & $9-12$ & $5-8$ & $13-16$ \\
\hline $\begin{array}{r}\Delta \\
1-4 \\
5-8 \\
9-12 \\
13-14\end{array}$ & $\begin{array}{c}21.06^{*} \\
10.71^{*} \\
13.14^{*} \\
8.39^{*}\end{array}$ & $\begin{array}{r}21.58^{*} \\
37.64^{*} \\
40.30^{*} \\
5.35^{*}\end{array}$ & $\begin{array}{c}11.90^{*} \\
17.20^{*} \\
32.07^{*} \\
1.05\end{array}$ & $\begin{array}{r}124.82^{*} \\
129.95^{*} \\
39.42^{*} \\
4.18^{*}\end{array}$ \\
\hline $\begin{array}{r}Z \\
1-4 \\
5-8 \\
9-12 \\
13-14\end{array}$ & $\begin{array}{c}161.87^{*} \\
158.68^{*} \\
9.49^{*} \\
2.83\end{array}$ & $\begin{array}{c}78.28^{*} \\
30.16^{*} \\
57.02^{*} \\
0.16\end{array}$ & $\begin{array}{c}41.12^{*} \\
12.10^{*} \\
33.77^{*} \\
1.70\end{array}$ & $\begin{array}{r}72.78^{*} \\
51.71^{*} \\
38.32^{*} \\
4.36^{*}\end{array}$ \\
\hline $\begin{array}{c}K \\
1-4 \\
5-8 \\
9-12 \\
13-14\end{array}$ & $\begin{array}{c}7.23 \\
33.08^{*} \\
11.87^{*} \\
1.39\end{array}$ & $\begin{array}{c}5.72 \\
11.34^{*} \\
36.35^{*} \\
1.51\end{array}$ & $\begin{array}{c}40.26^{*} \\
11.31^{*} \\
32.80^{*} \\
0.62\end{array}$ & $\begin{array}{c}25.12^{*} \\
28.57^{*} \\
21.47^{*} \\
2.34\end{array}$ \\
\hline $\begin{array}{c}\wedge \\
1-4 \\
5-8 \\
9-12 \\
13-14\end{array}$ & $\begin{array}{c}48.00^{*} \\
12.86^{*} \\
3.72 \\
0.81\end{array}$ & $\begin{array}{r}53.82^{*} \\
16.19^{*} \\
10.81^{*} \\
8.25^{*}\end{array}$ & $\begin{array}{c}51.00^{*} \\
18.78^{*} \\
2.39 \\
0.11\end{array}$ & $\begin{array}{c}11.76^{*} \\
20.02^{*} \\
4.33 \\
0.00\end{array}$ \\
\hline & $5-8^{b}$ & $13-16$ & $1-4$ & $9-12$ \\
\hline $\begin{array}{c}I \\
1=4 \\
5-8 \\
9-12 \\
13-14\end{array}$ & $\begin{array}{c}33.48^{*} \\
30.55^{*} \\
36.65^{*} \\
2.34\end{array}$ & $\begin{array}{c}15.27^{*} \\
15.94^{*} \\
6.31 \\
7.09^{*}\end{array}$ & $\begin{array}{r}39.97^{*} \\
24.63^{*} \\
48.26^{*} \\
7.57^{*}\end{array}$ & $\begin{array}{r}102.28^{*} \\
49.67^{*} \\
26.32^{*} \\
13.57^{*}\end{array}$ \\
\hline
\end{tabular}

a Chi-square values for each gate are found in Appendix II. feeding.

${ }_{\text {b }}$ ggregate feeding was switched with randomly scattered

*Significant departure from $\underline{\mathrm{H}}_{\underline{\mathrm{O}}}$ (the random use of space) at
ficance level. $5 \%$ significance level. 
Table 2. Chi-square values for goodness of fit tests for gate usages by Dipodomys microps for in behavior during 16 days.

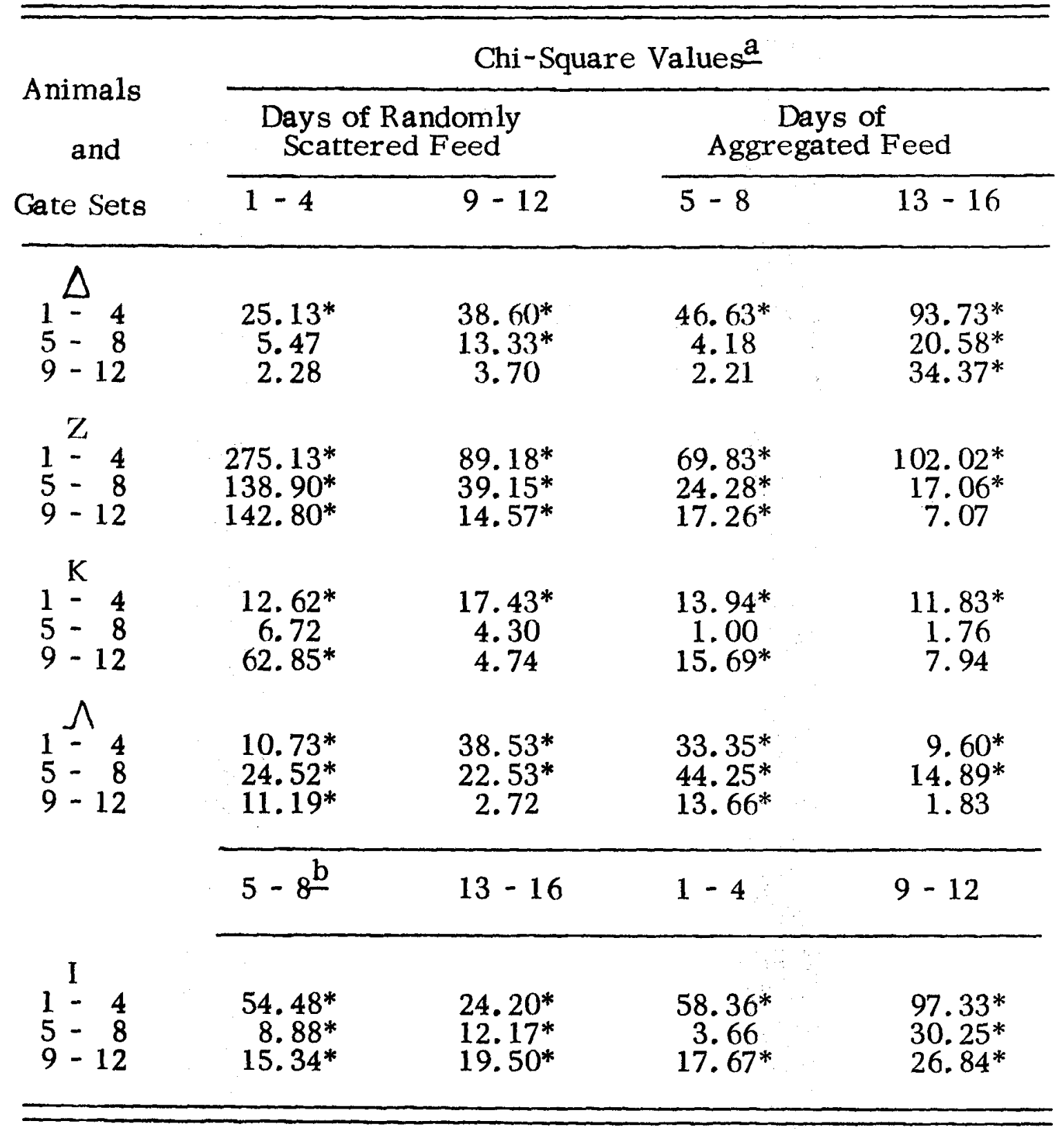

aChi-square values for each gate are found in Appendix II. b-Aggregate feeding was switched with randomly scattered feeding.

* Significant departure from $\underline{\mathrm{H}}_{\mathrm{O}}$ (the random use of space) at $5 \%$ significance level. 
Table 3. Chi-square values for goodness of fit tests for gate usages by Dipodomys microps for inter behavior during 16 days.

\begin{tabular}{|c|c|c|c|c|}
\hline \multirow{3}{*}{$\begin{array}{l}\text { Animals } \\
\text { and } \\
\text { Gate Sets }\end{array}$} & \multicolumn{4}{|c|}{ Chi-Square Values ${ }^{\mathrm{a}}$} \\
\hline & \multicolumn{2}{|c|}{$\begin{array}{l}\text { Days of Randomly } \\
\text { Scattered Feed }\end{array}$} & \multicolumn{2}{|c|}{$\begin{array}{c}\text { Days of } \\
\text { Aggregated Feed }\end{array}$} \\
\hline & $1-4$ & $9-12$ & $5-8$ & $13-16$ \\
\hline $\begin{array}{l}\Delta \\
5-8 \\
5-12 \\
9-14\end{array}$ & $\begin{array}{r}6.00 \\
10.03 \\
9.28\end{array}$ & $\begin{array}{c}0.99 \\
12.40 \\
31.36^{*}\end{array}$ & $\begin{array}{c}3.00 \\
6.16 \\
26.10^{*}\end{array}$ & $\begin{array}{r}0.00 \\
10.20 \\
6.35\end{array}$ \\
\hline $\begin{array}{l}Z \\
5-8 \\
5-12 \\
9-14\end{array}$ & $\begin{array}{l}25.78^{*} \\
71.81^{*} \\
41.21^{*}\end{array}$ & $\begin{array}{c}4.63 \\
17.98^{*} \\
8.70\end{array}$ & $\begin{array}{c}6.66 \\
41.31^{*} \\
8.88\end{array}$ & $\begin{array}{l}3.00 \\
6.00 \\
4.90\end{array}$ \\
\hline $\begin{array}{l}K \\
5-8 \\
5-12 \\
9-14\end{array}$ & $\begin{array}{c}6.50 \\
15.25^{*} \\
9.03^{*}\end{array}$ & $\begin{array}{r}3.66 \\
12.66 \\
3.68\end{array}$ & $\begin{array}{l}2.00 \\
3.58 \\
3.49\end{array}$ & $\begin{array}{l}0.00 \\
6.73 \\
1.98\end{array}$ \\
\hline $\begin{array}{l}\wedge \\
5-8 \\
5-12 \\
9-14\end{array}$ & $\begin{array}{l}0.00 \\
0.00 \\
7.00\end{array}$ & $\begin{array}{l}3.34 \\
4.02 \\
2.23\end{array}$ & $\begin{array}{r}3.00 \\
7.81 \\
10.39\end{array}$ & $\begin{array}{l}8.28^{*} \\
5.18 \\
4.87\end{array}$ \\
\hline & $5-8 b$ & $13-16$ & $1-4$ & $9-12$ \\
\hline $\begin{array}{l}I \\
5-8 \\
5-12 \\
9-14\end{array}$ & $\begin{array}{c}10.80^{*} \\
75.27^{*} \\
8.83\end{array}$ & $\begin{array}{c}7.34 \\
18.65^{*} \\
13.81^{*}\end{array}$ & $\begin{array}{c}1.22 \\
47.02^{*} \\
22.48^{*}\end{array}$ & $\begin{array}{r}8.27^{*} \\
265.94^{*} \\
186.83^{*}\end{array}$ \\
\hline
\end{tabular}

a Chi-square values for each gate are found in Appendix II. b Aggregate feeding was switched with randomly scattered feeding.

*Significant departure from $\underline{\mathrm{H}}_{\underline{\mathrm{O}}}$ (the random use of space) at
ficance level. $5 \%$ significance level. 
Chi-square values range from $0.00(\Delta$, inter, days 13 16, Table 3) to $278.42(\mathrm{Z}$, in, days $1-4$, Table 2$)$. Further variation is reflected by the total number of gates used for each feeding period by each animal (Tables 4 - 6). These values range from 3 gates $(1$, inter, days $1-4$, Table 6$)$ to 576 gates $(Z$, in, days $1-4$, Table 5). A multiple regression analyses (Abrcviated Dolittle) was used to teist for sources of significant variation in the se data (Tables $1-6)$.

The matrix was obtained (1) by determining the mean of the chi-square values for all gate sets and groups from each testing period for each animal (Tables $1-3$ ) and (2) by transforming the total number of gates for each testing period and for each animal. Both modified chi-square values and transformed gate totals were tested with each of the three behaviors and each of these six variables was run independently of the other five to test the following possible sources of error: (a) sequence of feeding periods, i. e., (1), (2), (3), (4) and (2), (1), (4), (3) (see p. 6); (b) periods i.e., the first period vs. the second, the first vs. the third, and the first vs. the fourth; (c) inter-animal variation; (d) interaction of sequence of periods and periods; (e) distribution of feed, i. e., randomly scattered and aggregated.

Results from the analysis of modified chi-square values (Table 7) show no significant $F$-ratios from any source for ex and in behaviors. Sequence of feeding periods $(S)$, periods $(P)$, interaction (S X P), and random vs. aggregate feeding are significant while inter-animal variation is non-significant. Results from the analysis of transformed gate totals (Table 8) indicate significant F-ratios from the inter-animal source of error for ex and in 
behavior. No other sources were significant for ex and in behavior. Sequence of feeding is the only significant F-ratio during inter behavior. 
Table 4. Total number of gate usages by Dipodomys microps for ex behavior during 16 days.

\begin{tabular}{clccc}
\hline & \multicolumn{4}{c}{ Gate Usages } \\
\cline { 2 - 5 } Animals & \multicolumn{2}{c}{$\begin{array}{c}\text { Days of Randomly } \\
\text { Scattered Feed }\end{array}$} & \multicolumn{2}{c}{$\begin{array}{c}\text { Days of } \\
\text { Aggregated Fecd }\end{array}$} \\
\cline { 2 - 5 } & $1-4$ & $9-12$ & $5-8$ & $13-16$ \\
\hline Z & 106 & 155 & 125 & 162 \\
$\mathrm{~K}$ & 572 & 265 & 247 & 157 \\
$\Lambda$ & 427 & 165 & 233 & 87 \\
& 46 & 119 & 60 & 61 \\
$\mathrm{n}$ & $5-8$ & $13-16$ & $1-4$ & $9-12$ \\
\cline { 2 - 6 } & 369 & 181 & 437 & 412 \\
\hline
\end{tabular}
feeding.

a Agregate feeding was switched with randomly scattered 
Table 5. Total number of gate usages by Dipodomys microps for in behavior during 16 days.

Gate Usages

\begin{tabular}{cccccc}
\multirow{2}{*}{ Animals } & \multicolumn{2}{c}{$\begin{array}{c}\text { Days of Randomly } \\
\text { Scattered Feed }\end{array}$} & & \multicolumn{2}{c}{ Days of } \\
\cline { 2 - 3 } \cline { 5 - 6 } & $1-4$ & $9-12$ & & $5-8$ & $13-16$ \\
\hline$\Delta$ & 115 & 156 & 123 & 191 \\
$\mathrm{Z}$ & 576 & 263 & 247 & 157 \\
$\mathrm{~K}$ & 418 & 169 & 225 & 88 \\
$\Lambda$ & 45 & 120 & 59 & 72 \\
\cline { 2 - 6 } & $5-8$ a & $13-16$ & $1-4$ & $9-12$ \\
\hline & 349 & 165 & 424 & 389 \\
\hline
\end{tabular}
feeding.

a Aggregate feeding was switched with randomly scattered 
Table 6. Total number of gate usages by Dipodomys microps for inter behavior during 16 days.

\begin{tabular}{cccccc}
\hline & \multicolumn{4}{c}{ Gate Usages } \\
\cline { 2 - 5 } Animals & \multicolumn{2}{c}{$\begin{array}{c}\text { Days of Randomly } \\
\text { Scattered Feed }\end{array}$} & & \multicolumn{2}{c}{$\begin{array}{c}\text { Days of } \\
\text { Aggregated Feed }\end{array}$} \\
\cline { 2 - 6 } & $1-4$ & $9-12$ & & $5-8$ & $13-16$ \\
\hline$\Delta$ & 42 & 48 & 31 & 12 \\
$Z$ & 276 & 69 & 112 & 4 \\
$\mathrm{~K}$ & 138 & 18 & 33 & 5 \\
$\Lambda$ & 3 & 31 & 18 & 51 \\
\cline { 2 - 6 } & $5-8 \mathrm{a}$ & $13-16$ & $1-4$ & $9-12$ \\
\hline
\end{tabular}
feeding.

a Aggregate feeding was switched with randomly scattered 
Table 7. Summary of multiple regression analyses of modified chi-square values from Tables $1-3$ for Dipodomys microps.

\begin{tabular}{|c|c|c|c|c|c|c|c|c|c|c|}
\hline \multirow{2}{*}{$\begin{array}{l}\text { Source } \\
\text { of } \\
\text { Error }\end{array}$} & \multirow[b]{2}{*}{ d.f. } & \multicolumn{3}{|c|}{ Ex Behavior } & \multicolumn{3}{|c|}{ In Behavior } & \multicolumn{3}{|c|}{ Inter Behavior } \\
\hline & & $\begin{array}{l}\text { Sum of } \\
\text { Squares }\end{array}$ & $\begin{array}{l}\text { Mean } \\
\text { Squares }\end{array}$ & $\begin{array}{c}F- \\
\text { ratio }\end{array}$ & $\begin{array}{l}\text { Sum of } \\
\text { Squares }\end{array}$ & $\begin{array}{l}\text { Mean } \\
\text { Squares }\end{array}$ & $\underset{\text { ratio }}{\mathrm{F}-}$ & $\begin{array}{l}\text { Sum of } \\
\text { Squares }\end{array}$ & $\begin{array}{l}\text { Mean } \\
\text { Squares }\end{array}$ & $\begin{array}{c}\mathrm{F}- \\
\text { ratio }\end{array}$ \\
\hline Mean & 1 & 16060.00 & & & 21883.00 & & & 7397.00 & & \\
\hline $\begin{array}{l}\text { Sequence of } \\
\text { Feeding (S) }\end{array}$ & 1 & 0.83 & 0.83 & 0.00 & 27.80 & 27.80 & 0.01 & 6590.60 & 6590.60 & $33.38^{*}$ \\
\hline Periods (P) & 3 & 405.82 & 135.27 & 0.25 & 2777.40 & 925.80 & 0.57 & 2651.10 & 883.70 & $6.46^{*}$ \\
\hline Animals & 3 & 2568.95 & 856.32 & 1.58 & 10763.06 & 3587.69 & 2.19 & 592.38 & 197.46 & 1.44 \\
\hline$S \times P$ & 3 & 825.54 & 308.54 & 0.47 & 1518.30 & 506.53 & 0.23 & 10661.40 & 3553.73 & $25.99 *$ \\
\hline $\begin{array}{l}\text { Random vs } \\
\text { Aggregate } \\
\text { Feeding }\end{array}$ & 1 & 306.39 & 306.39 & 0.47 & 0.00 & 0.00 & 0.00 & 2962.40 & 2962.40 & $21.66^{*}$ \\
\hline Residual & 2 & 619.22 & & & 1519.60 & & & 7698.80 & & \\
\hline Error & 6 & 3949.33 & 658.22 & & 13194.78 & 2199.13 & & 820.40 & 136.74 & \\
\hline Total & 17 & 23910.15 & & & 50165.58 & & & 27892.31 & & \\
\hline
\end{tabular}

${ }^{*} \mathrm{~F}$-ratio is significant at the $5 \%$ level. 
Table 8. Summary of multiple regression analyses of transformed total gate numbers from Tables 1 3 for Dipodomys microps.

\begin{tabular}{|c|c|c|c|c|c|c|c|c|c|c|}
\hline \multirow{2}{*}{$\begin{array}{c}\text { Source } \\
\text { of } \\
\text { Error }\end{array}$} & \multirow[b]{2}{*}{ d.f. } & \multicolumn{3}{|c|}{ Ex Behavior } & \multicolumn{3}{|c|}{ In Behavior } & \multicolumn{3}{|c|}{ Inter Behavior } \\
\hline & & $\begin{array}{l}\text { Sum of } \\
\text { Squares }\end{array}$ & $\begin{array}{c}\text { Mean } \\
\text { Squares }\end{array}$ & s ratio & $\begin{array}{l}\text { Sum of } \\
\text { Squares }\end{array}$ & $\begin{array}{c}\text { Mean } \\
\text { Squares }\end{array}$ & $\begin{array}{c}\mathrm{F}- \\
\text { ratio }\end{array}$ & $\begin{array}{l}\text { Sum of } \\
\text { Squares }\end{array}$ & $\begin{array}{c}\text { Mean } \\
\text { Squares }\end{array}$ & $\begin{array}{c}\mathrm{F}- \\
\text { ratio }\end{array}$ \\
\hline Mean & 1 & 3929.00 & & & 3922.50 & & & 1222.60 & & \\
\hline $\begin{array}{l}\text { Sequence of } \\
\text { Feeding (S) }\end{array}$ & 1 & 98.97 & 98.97 & 1.73 & 78.23 & 78.33 & 1.44 & 158.29 & 158.29 & $10.19 *$ \\
\hline Periods (P) & 3 & 73.30 & $24.43 \quad 1$ & 1.94 & 66.29 & 22.10 & 1.64 & 73.78 & 24.59 & 1.30 \\
\hline Animals & 3 & 171.82 & 57.27 & $4.55^{*}$ & 162.61 & 54.20 & $4.01^{*}$ & 50.53 & 16.84 & 0.89 \\
\hline S X P & 3 & 9.07 & 3.02 & 0.17 & 11.52 & 3.84 & 0.21 & 46.58 & 15.53 & 0.76 \\
\hline $\begin{array}{l}\text { Random v } \\
\text { Aggregat } \\
\text { Feeding }\end{array}$ & 1 & 1.90 & 1.90 & 0.11 & 2.55 & 2.55 & 0,14 & 1.13 & 1.13 & 0.06 \\
\hline Residual & 2 & 7.17 & & & 8.97 & & & 45.45 & & \\
\hline Error & 6 & 104.11 & 17.35 & & 109.97 & 18.33 & & 123.38 & 20.56 & \\
\hline Totals & 17 & 4386.21 & & & 4351.17 & & & 1675.13 & & \\
\hline
\end{tabular}

${ }^{*} \mathrm{~F}$-ratio is significant at the $5 \%$ level. 


\section{DISCUSSION AND CONCLUSIONS}

Studies of spatial activity patterns for Dipodomys spp or any of the other heteromyids were not available in the literature. Yet an . understanding of space usage within the home range of single organisms is an essential step toward increasing the fidelity of activity models for small mammal populations. The kangaroo rat (D. microps) used space non-randomly in the simulated home range.

The kangaroo rats were studied in an area much smaller than their normal-size home range area, but there is reason to believe that they would use a much larger area in a similar non-random manner. Jorgensen (personal communication) has observed beaten paths radiating from the burrows of $D$. microps. Other mammals' repeated use of certain pathways also suggests a non-random space usage. These pathways have been described from the animals' burrows to a stationary food source for Peromyscus polionotus (Wagner) (Blair, 1951); between grass clumps for Microtus californicus (Peale) and Reithrodonotomys megalotis (Baird) (Pearson, 1959); along tree trunks for Citellus beecheyi (Richardson) (Adams and Davis, 1967); and along ramps and shelves for Mus musculus Linnaeus (Calhoun, 1956). Other workers have also indicated non-random usage of space (Brown, 1966; Siniff and Jesson, 1969). The ordered usage of space by $D$. microps agrees with general field observations and represents a much needed step in the quantification of space usage. Implications of this study can be understood better after a 
brief review of the technique of density probability function for estimating home range. The probability of encountering an animal at a given distance from its center of activity was introduced by Hayne (1949). More precise estimates of these distance probabilities and the use of concentric zones of variable space usage around a center of activity followed (Dice and Clark, 1953; Calhoun and Casby, 1958). Based on the concept of circular home range estimates, Jorgensen (1968a, 1968b) and Speth (1969) used methods for estimating varying levels of probable interaction of small mammals when portions of the circular home ranges overlapped. They assumed that only two animals were in the overlap region at the same time and that these two animals had equal probability of being there and interacting. When the corrals of the activity arena are conceived of as intensity of use zones, with the nest can as a center of activity, the animals entered each corral or use zone through certain gates or from certain directions significantly more often than others. This demonstrated preference for gate usages permits the conclusion that the non-random use of space does not necessarily alter the probability of an animal being a specified distance from its center of activity, but it does challenge the notion that an animal may be encountered with equal probability in any specified direction from the center. Thus, within one intensity of use zone the animal may be more likely encountered in a northeasterly direction whereas in another zone it may be found more often in a westerly direction, etc. This partitioning of probabilities for distance and direction from the center of activity suggests that animals may vary in their usage of overlapping portions of their home ranges and interact with other 
animals either more or less frequently than presently thought. In future studies of probable interaction of small mammals, the above implication should be considered.

An understanding of how one organism uses its space in relation to another is also important in predicting the rate of disease transmittance through a rodent population (Mohr and Stumpf, 1964), the number of male-female encounters and a knowledge of gene flow, reproductive behavior, and use intensity of space. In addition, Sanderson (1966) recommends increased attention be given to fundamental behavior patterns of mammals so that management and control programs can be improved. 
SUMMARY

Great Basin kangaroo rats, D. microps, were placed into an activity arena one at a time. Their usage patterns of gates that were placed in various concentric fences were recorded and evaluated with the chi-square goodness of fit test for possible deviation from randomness. The possible effects of randomly dispersed and aggregated feed upon gate usage patterns of the animals while in the arena were evaluated with a multiple regression analyses.

The following three movement behaviors were assumed: $\underline{\mathrm{ex}}$, movement away from a centralized nest can; in, movement toward the nest can; and inter, movement free of association with the nest can. All animals used the gates preferentially in the arena during ex, in, and inter behavior. Distribution patterns of feed did not represent a significant source of error in the analyses of space usage.

This non-random usage of space challenges an assumption in studies where circular home range estimates are used to estimate probable interaction among small mammals. It suggests that future research should consider the probability of being a given distance as , well as the probability of being a given direction from a center of activity. 


\section{LITERATURE CITED}

Adams, L. and S. D. Davis. 1967. The internal anatomy of home range. J . Mammal. 48:529-536.

Blair, W. F. 1951. Population structure, social behavior, and environmental relations in a natural population of the beach mouse (Peromyscus polionotus leucocephalus). Univ. Mich. Contr. Lab. Vert. Zool. No. 48:1-47.

Brown, L. E. 1966. Home range and movement of small mammals. Symp. Zool. Soc. Longon. 18:111-142.

Burge, J. R. 1967. Determining a reliable estimate of home range for small mammals. Unpublished Masters Thesis, Brigham Young University. Provo, Utah. $39 \mathrm{pp}$.

Burt, W. H. 1943. Territoriality and home range concepts as applied to mammals. J. Mammal. 24:346-352.

Calhoun, J. B. 1956. Behavior of house mice with reference to fixed points of orientation. Ecol. 37:287-301.

Calhoun, J. B. and J. V. Casby. 1958. Calculation of home range and density of small mammals. U.S. Publ. Hlth. Monogr. $55: 1-12$.

Dice, L. R. and P. J. Clark. 1953. The statistical concept of home range as applied to the recapture radius of the deer mouse (Peromyscus). Univ. Mich. Contr. Lab. Vert. Zool. No. 62:1-23.

Durrant, S. D. 1952. Mammals of Utah. Univ. Kans. Publ., Mus. Nat. Hist. No. 6. 549 pp. 
Ghent, A. W. 1967. Selected problems in biometry. Part 3. Chisquare as an index of disagreement. Bios. 38:161-179.

Harrison, J. L. 1958. Range of movement of some Malayan rats.

J. Mammal. 39:190-206.

Hayne, D. W. 1949. Calculation of size of home range. J. Mammal. $30: 1-18$.

Jorgensen, C. D. 1968a. Home range as a measure of probable interaction among populations of small mammals. J.

Mammal. 49:104-112.

- 1968b. Spatial relationships of Perognathus longimembris (Coues) in southern Nevada. Proc. Utah Acad. of Art., Sci., and Letters. 45:118-125.

Miller, G. S., Jr. and R. Kellogg. 1955. List of North American recent mammals. Washington, D. C. U. S. Nat. Mus. Bull. 205. 954 pp.

Mohr, C. O. and W. A. Stumpf. 1964. Relation of tick and chigger infestations to home areas of California meadow mice. J. Med. Ent. 1:73-77.

Ostle, H. D. 1964. Statistics in research. Iowa State Univ. Press, Ames. $585 \mathrm{pp}$.

Pearson, O. P. 1959. A traffic survey of Microtus-Reithrodontomys runways. J. Mammal. 40:169-180.

Sanderson, G. C. 1966. The study of mammal movements - a review. J. Wildl. Mgmt. 30:215-235.

Siniff, D. B. and C. R. Jesson. 1969. A simulation model of animal movement patterns, pp. 185-219. In J. B. Cragg (ed.) Advances in ecological research. Academic Press, New York. 
Speth, R. L. 1969. Social structure of small mammal populations at the National Reactor Testing Station, Idaho. Unpublished Doctors Dissertation, Brigham Young University. Provo, Utah. $134 \mathrm{pp}$. 
APPENDIX I

Matrix of distances between gates (in $\mathrm{cm}$ ) in the activity arena, used to compute activity patterns of Dipodomys microps (Merriam). 


\begin{tabular}{|c|c|c|c|c|c|c|c|c|c|c|c|c|}
\hline \multicolumn{13}{|c|}{ Gate } \\
\hline Gate & 1 & 2 & 3 & 4 & 5 & 6 & 7 & 8 & 9 & 10 & 11 & 12 \\
\hline 1 & $\cdots-$ & & & & & & & & & & & \\
\hline 2 & 34.29 & ---- & & & & & & & & & & - \\
\hline 3 & 69.22 & 34.93 & $\cdots$ & & & & & & & & & \\
\hline 43 & 34.93 & 68.58 & 33.66 & ---- & & & & & & & & \\
\hline $5:$ & 33.02 & 65.41 & 65.41 & 33.02 & $-\cdots-\cdots$ & & & & & & & \\
\hline 64 & 45.09 & 33.66 & 60.96 & 80.01 & 96.52 & $-\cdots---$ & & & & & & \\
\hline 7 & 66.04 & 33.02 & 33.66 & 66.04 & 158.75 & 64.14 & $\cdots-\cdots$ & & & & & \\
\hline 8 & 60.33 & 80.01 & 45.09 & 34.29 & 64.14 & 158.75 & 98.43 & $---\cdots$ & & & & \\
\hline 9 & & & & & 46.99 & 53.98 & 118.11 & 109.86 & $-\ldots--$ & & & \\
\hline 10 & & & & & 133.99 & 43.18 & 51.44 & 147.96 & 124.46 & $-\cdots$ & & \\
\hline 11 & & & & & 115.57 & 111.76 & 48.26 & 51.44 & 252.73 & 127.64 & ----- & \\
\hline 12 & & & & & 50.80 & 146.69 & 137.16 & 42.55 & 127.00 & 249.56 & 127.00 &.----- \\
\hline 13 & & & & & & & & & 179.07 & 222.89 & 95.89 & 55.88 \\
\hline 14 & & & & & & & & & 97.16 & 54.61 & 178.44 & 222.25 \\
\hline
\end{tabular}




\section{APPENDIX II}

\section{Gate Usages}

Each gate usage is presented for each animal as one of three recognized behaviors: (1) ex, (2) in, and (3) inter. Observed and expected usages are given for each gate and for each four day feeding period. Chi-square values are also shown for each gate, each gate set, and each four day period. 
$\Delta \underline{E x}$

\begin{tabular}{|c|c|c|c|c|c|c|c|c|c|c|c|c|}
\hline \multirow{3}{*}{$\begin{array}{l}\text { Gate } \\
\text { No. }\end{array}$} & \multicolumn{11}{|c|}{ Days } & \\
\hline & \multicolumn{3}{|c|}{$1-4$} & \multicolumn{3}{|c|}{$5-8$} & \multicolumn{3}{|c|}{$9-12$} & \multicolumn{3}{|c|}{$13-16$} \\
\hline & Obs. & Exp. & $x^{2}$ & Obs. & Exp. & $x^{2}$ & Obs. & Exp. & $x^{2}$ & Obs. & Exp. & $x^{2}$ \\
\hline $\begin{array}{l}1 \\
2 \\
3 \\
4\end{array}$ & $\begin{array}{r}4 \\
21 \\
8 \\
4\end{array}$ & $\begin{array}{l}9.25 \\
9.25 \\
9.25 \\
9.25\end{array}$ & $\begin{array}{r}2.98 \\
14.93 \\
0.17 \\
2.98\end{array}$ & $\begin{array}{r}5 \\
18 \\
10 \\
5\end{array}$ & $\begin{array}{l}9.50 \\
9.50 \\
9.50 \\
9.50\end{array}$ & $\begin{array}{l}2.13 \\
7.61 \\
0.03 \\
2.13\end{array}$ & $\begin{array}{r}11 \\
22 \\
12 \\
0\end{array}$ & $\begin{array}{l}11.25 \\
11.25 \\
11.25 \\
11.25\end{array}$ & $\begin{array}{r}0.01 \\
10.27 \\
0.05 \\
11.25\end{array}$ & $\begin{array}{r}3 \\
49 \\
2 \\
0\end{array}$ & $\begin{array}{l}13.50 \\
13.50 \\
13.50 \\
13.50\end{array}$ & $\begin{array}{r}8.17 \\
93.35 \\
9.80 \\
13.50\end{array}$ \\
\hline Totals & 37 & & 21.06 & 38 & & 11.90 & 45 & & 21.58 & 54 & & 124.82 \\
\hline $\begin{array}{l}5 \\
6 \\
7 \\
8\end{array}$ & $\begin{array}{r}4 \\
10 \\
4 \\
12\end{array}$ & $\begin{array}{l}6.44 \\
8.35 \\
9.31 \\
5.86\end{array}$ & $\begin{array}{l}0.92 \\
0.33 \\
3.03 \\
6.43\end{array}$ & $\begin{array}{r}5 \\
4 \\
5 \\
15\end{array}$ & $\begin{array}{l}6.49 \\
7.70 \\
8.79 \\
6.01\end{array}$ & $\begin{array}{r}0.34 \\
1.78 \\
1.63 \\
13.45\end{array}$ & $\begin{array}{r}2 \\
9 \\
6 \\
22\end{array}$ & $\begin{array}{r}8.64 \\
10.99 \\
11.97 \\
7.35\end{array}$ & $\begin{array}{r}5.10 \\
0.36 \\
2.98 \\
29.20\end{array}$ & $\begin{array}{r}\frac{2}{13} \\
1 \\
37\end{array}$ & $\begin{array}{r}9.78 \\
17.41 \\
17.81 \\
7.92\end{array}$ & $\begin{array}{r}6.19 \\
1.12 \\
15.87 \\
106.77\end{array}$ \\
\hline Totals & 30 & & 10.71 & 29 & & 17.20 & 39 & & 37.64 & 53 & & 129.95 \\
\hline $\begin{array}{r}9 \\
10 \\
11 \\
12\end{array}$ & $\begin{array}{r}3 \\
11 \\
1 \\
12\end{array}$ & $\begin{array}{l}6.45 \\
6.60 \\
6.83 \\
7.10\end{array}$ & $\begin{array}{l}1.85 \\
2.93 \\
4.98 \\
3.38\end{array}$ & $\begin{array}{r}0 \\
6 \\
1 \\
22\end{array}$ & $\begin{array}{l}6.23 \\
5.73 \\
8.17 \\
8.85\end{array}$ & $\begin{array}{r}6.23 \\
0.01 \\
6.29 \\
19.54\end{array}$ & $\begin{array}{r}0 \\
7 \\
2 \\
27\end{array}$ & $\begin{array}{r}7.35 \\
7.87 \\
10.31 \\
10.46\end{array}$ & $\begin{array}{r}7.35 \\
0.10 \\
6.70 \\
26.15\end{array}$ & $\begin{array}{r}0 \\
1 \frac{2}{2} \\
32\end{array}$ & $\begin{array}{r}9.37 \\
8.80 \\
12.92 \\
14.89\end{array}$ & $\begin{array}{r}9.37 \\
1.16 \\
9.23 \\
19.66\end{array}$ \\
\hline Totals & 27 & & 13.14 & 29 & & 32.07 & 36 & & 40.30 & 46 & & 39.42 \\
\hline $\begin{array}{l}13 \\
14\end{array}$ & $\begin{array}{r}11 \\
1\end{array}$ & $\begin{array}{l}5.98 \\
6.01\end{array}$ & $\begin{array}{l}4.21 \\
4.18\end{array}$ & $\begin{array}{r}22 \\
7\end{array}$ & $\begin{array}{r}19.41 \\
9.59\end{array}$ & $\begin{array}{l}.35 \\
.70\end{array}$ & $\begin{array}{r}30 \\
5\end{array}$ & $\begin{array}{l}23.58 \\
11.41\end{array}$ & $\begin{array}{l}1.75 \\
3.60\end{array}$ & $\begin{array}{l}3 \\
6\end{array}$ & $\begin{array}{l}6.55 \\
3.28\end{array}$ & $\begin{array}{l}1.92 \\
2.26\end{array}$ \\
\hline Totals & 12 & & 8.39 & 29 & & 1.05 & 35 & & 5.35 & 9 & & 4.18 \\
\hline
\end{tabular}




\section{$\mathrm{Z}$ Ex}

\begin{tabular}{|c|c|c|c|c|c|c|c|c|c|c|c|c|}
\hline \multirow{3}{*}{$\begin{array}{c}\text { Gate } \\
\text { No. }\end{array}$} & \multicolumn{12}{|c|}{ Days } \\
\hline & \multicolumn{3}{|c|}{$1-4$} & \multicolumn{3}{|c|}{$5-8$} & \multicolumn{3}{|c|}{$9-12$} & \multicolumn{3}{|c|}{$13-16$} \\
\hline & Obs. & Exp. & $x^{2}$ & Obs. & Exp. & $x^{2}$ & Obs. & Exp. & $x^{2}$ & Obs. & Exp. & $x^{2}$ \\
\hline $\begin{array}{l}1 \\
2 \\
3 \\
4\end{array}$ & $\begin{array}{r}20 \\
27 \\
15 \\
119\end{array}$ & $\begin{array}{l}45.25 \\
45.25 \\
45.25 \\
45.25\end{array}$ & $\begin{array}{r}14.09 \\
7.36 \\
20.22 \\
120.20\end{array}$ & $\begin{array}{r}27 \\
1 \\
9 \\
35\end{array}$ & $\begin{array}{l}18.00 \\
18.00 \\
18.00 \\
18.00\end{array}$ & $\begin{array}{r}4.50 \\
16.06 \\
4.50 \\
16.06\end{array}$ & $\begin{array}{r}18 \\
0 \\
6 \\
49\end{array}$ & $\begin{array}{l}18.25 \\
18.25 \\
18.25 \\
18.25\end{array}$ & $\begin{array}{r}0.00 \\
18.25 \\
8.22 \\
51.81\end{array}$ & $\begin{array}{r}4 \\
3 \\
2 \\
36\end{array}$ & $\begin{array}{l}11.25 \\
11.25 \\
11.25 \\
11.25\end{array}$ & $\begin{array}{r}4.67 \\
6.05 \\
7.61 \\
54.45\end{array}$ \\
\hline Totals & 181 & & 161.87 & 72 & & 41.12 & 73 & & 78.28 & 45 & & 72.78 \\
\hline $\begin{array}{l}5 \\
6 \\
7 \\
8\end{array}$ & $\begin{array}{l}27 \\
99 \\
19 \\
31\end{array}$ & $\begin{array}{l}54.47 \\
33.48 \\
37.70 \\
50.18\end{array}$ & $\begin{array}{r}13.85 \\
128.22 \\
9.28 \\
7.33\end{array}$ & $\begin{array}{r}17 \\
24 \\
8 \\
23\end{array}$ & $\begin{array}{l}23.71 \\
14.26 \\
14.41 \\
19.56\end{array}$ & $\begin{array}{l}1.90 \\
6.65 \\
2.85 \\
0.60\end{array}$ & $\begin{array}{r}13 \\
25 \\
3 \\
32\end{array}$ & $\begin{array}{l}24.63 \\
12.98 \\
13.81 \\
21.54\end{array}$ & $\begin{array}{r}5.49 \\
11.13 \\
8.46 \\
5.08\end{array}$ & $\begin{array}{r}1 \\
24 \\
4 \\
15\end{array}$ & $\begin{array}{r}14.52 \\
7.47 \\
8.49 \\
13.49\end{array}$ & $\begin{array}{r}12.59 \\
36.58 \\
2.37 \\
0.77\end{array}$ \\
\hline Totals & 176 & & 158.68 & 72 & & 12.10 & 73 & & 30.16 & 44 & & 51.71 \\
\hline $\begin{array}{l}9 \\
10 \\
11 \\
12\end{array}$ & $\begin{array}{l}57 \\
43 \\
21 \\
26\end{array}$ & $\begin{array}{l}41.42 \\
44.86 \\
30.62 \\
30.00\end{array}$ & $\begin{array}{l}5.86 \\
0.08 \\
3.02 \\
0.53\end{array}$ & $\begin{array}{r}7 \\
24 \\
3 \\
33\end{array}$ & $\begin{array}{l}17.51 \\
16.14 \\
15.65 \\
17.63\end{array}$ & $\begin{array}{r}6.31 \\
3.83 \\
10.23 \\
13.40\end{array}$ & $\begin{array}{r}3 \\
21 \\
0 \\
41\end{array}$ & $\begin{array}{l}16.28 \\
14.72 \\
15.57 \\
18.36\end{array}$ & $\begin{array}{r}10.83 \\
2.70 \\
15.57 \\
27.92\end{array}$ & $\begin{array}{r}0 \\
21 \\
0 \\
19\end{array}$ & $\begin{array}{r}10.02 \\
11.76 \\
9.36 \\
8.84\end{array}$ & $\begin{array}{r}10.02 \\
7.26 \\
9.36 \\
11.68\end{array}$ \\
\hline Totals & 147 & & 9.49 & 67 & & 33.77 & 65 & & 57.02 & 40 & & 38.32 \\
\hline $\begin{array}{l}13 \\
14\end{array}$ & $\begin{array}{l}36 \\
32\end{array}$ & $\begin{array}{l}29.14 \\
38.90\end{array}$ & $\begin{array}{l}1.61 \\
1.22\end{array}$ & $\begin{array}{l}23 \\
13\end{array}$ & $\begin{array}{l}19.09 \\
16.90\end{array}$ & $\begin{array}{l}0.80 \\
0.90\end{array}$ & $\begin{array}{l}33 \\
21\end{array}$ & $\begin{array}{l}31.53 \\
22.46\end{array}$ & $\begin{array}{l}0.07 \\
0.09\end{array}$ & $\begin{array}{r}8 \\
20\end{array}$ & $\begin{array}{l}13.52 \\
14.47\end{array}$ & $\begin{array}{l}2.25 \\
2.11\end{array}$ \\
\hline Totals & 68 & & 2.83 & 36 & & 1.70 & 54 & & 0.16 & 28 & & 4.36 \\
\hline
\end{tabular}


$\mathrm{K}$ Ex

\begin{tabular}{|c|c|c|c|c|c|c|c|c|c|c|c|c|}
\hline \multirow{3}{*}{$\begin{array}{c}\text { Gate } \\
\text { No. }\end{array}$} & \multicolumn{11}{|c|}{ Days } & \\
\hline & \multicolumn{3}{|c|}{$1-4$} & \multicolumn{3}{|c|}{$5-8$} & \multicolumn{3}{|c|}{$9-12$} & \multicolumn{3}{|c|}{$13-16$} \\
\hline & Obs. & Exp. & $x^{2}$ & Obs. & Exp. & $x^{2}$ & Obs. & Exp. & $X^{2}$ & Obs. & Exp. & $x^{2}$ \\
\hline $\begin{array}{l}1 \\
2 \\
3 \\
4\end{array}$ & $\begin{array}{l}31 \\
41 \\
21 \\
38\end{array}$ & $\begin{array}{l}32.75 \\
32.75 \\
32.75 \\
32.75\end{array}$ & $\begin{array}{l}0.09 \\
2.08 \\
4.22 \\
0.84\end{array}$ & $\begin{array}{r}9 \\
19 \\
5 \\
40\end{array}$ & $\begin{array}{l}18.25 \\
18.25 \\
18.25 \\
18.25\end{array}$ & $\begin{array}{r}4.69 \\
0.03 \\
9.62 \\
25.92\end{array}$ & $\begin{array}{r}16 \\
7 \\
13 \\
19\end{array}$ & $\begin{array}{l}13.75 \\
13.75 \\
13.75 \\
13.75\end{array}$ & $\begin{array}{l}0.37 \\
3.31 \\
0.04 \\
2.00\end{array}$ & $\begin{array}{r}4 \\
22 \\
5 \\
5\end{array}$ & $\begin{array}{l}9.00 \\
9.00 \\
9.00 \\
9.00\end{array}$ & $\begin{array}{r}2.78 \\
18.78 \\
1.78 \\
1.78\end{array}$ \\
\hline Totals & 131 & & 7.23 & 73 & & 40.26 & 55 & & 5.72 & 36 & & 25.12 \\
\hline $\begin{array}{l}5 \\
6 \\
7 \\
8\end{array}$ & $\begin{array}{l}58 \\
31 \\
11 \\
23\end{array}$ & $\begin{array}{l}33.19 \\
29.67 \\
31.64 \\
28.36\end{array}$ & $\begin{array}{r}18.55 \\
0.06 \\
13.46 \\
1.01\end{array}$ & $\begin{array}{r}19 \\
23 \\
6 \\
19\end{array}$ & $\begin{array}{l}19.61 \\
14.24 \\
15.47 \\
17.61\end{array}$ & $\begin{array}{l}0.02 \\
5.38 \\
5.79 \\
0.11\end{array}$ & $\begin{array}{r}7 \\
15 \\
6 \\
18\end{array}$ & $\begin{array}{r}13.33 \\
9.91 \\
11.00 \\
11.66\end{array}$ & $\begin{array}{l}3.01 \\
2.61 \\
2.27 \\
3.45\end{array}$ & $\begin{array}{r}3 \\
19 \\
1 \\
2\end{array}$ & $\begin{array}{l}5.50 \\
7.08 \\
7.60 \\
4.80\end{array}$ & $\begin{array}{r}1.14 \\
20.07 \\
5.73 \\
1.63\end{array}$ \\
\hline Totals & 123 & & 33.08 & 67 & & 11.31 & 46 & & 11.34 & 25 & & 28.57 \\
\hline $\begin{array}{l}9 \\
10 \\
11 \\
12\end{array}$ & $\begin{array}{r}37 \\
29 \\
9 \\
40\end{array}$ & $\begin{array}{l}34.44 \\
24.84 \\
23.61 \\
32.10\end{array}$ & $\begin{array}{l}0.19 \\
0.70 \\
9.04 \\
1.94\end{array}$ & $\begin{array}{r}5 \\
30 \\
5 \\
26\end{array}$ & $\begin{array}{l}18.08 \\
15.83 \\
14.73 \\
17.42\end{array}$ & $\begin{array}{r}9.46 \\
12.68 \\
6.43 \\
4.23\end{array}$ & $\begin{array}{r}1 \\
18 \\
0 \\
22\end{array}$ & $\begin{array}{r}9.91 \\
9.93 \\
10.28 \\
10.84\end{array}$ & $\begin{array}{r}8.01 \\
6.66 \\
10.28 \\
11.50\end{array}$ & $\begin{array}{r}1 \\
17 \\
0 \\
3\end{array}$ & $\begin{array}{l}6.46 \\
7.26 \\
3.72 \\
3.55\end{array}$ & $\begin{array}{r}4.61 \\
13.07 \\
3.72 \\
0.09\end{array}$ \\
\hline Totals & 115 & & 11.87 & 66 & & 32.80 & 41 & & 36.35 & 21 & & 21.47 \\
\hline $\begin{array}{l}13 \\
14\end{array}$ & $\begin{array}{l}33 \\
25\end{array}$ & $\begin{array}{l}28.51 \\
29.47\end{array}$ & $\begin{array}{l}0.71 \\
0.68\end{array}$ & $\begin{array}{l}15 \\
12\end{array}$ & $\begin{array}{l}12.97 \\
14.05\end{array}$ & $\begin{array}{l}0.32 \\
0.30\end{array}$ & $\begin{array}{r}15 \\
8\end{array}$ & $\begin{array}{l}12.05 \\
10.95\end{array}$ & $\begin{array}{l}0.72 \\
0.79\end{array}$ & $\begin{array}{l}3 \\
2\end{array}$ & $\begin{array}{l}1.45 \\
3.55\end{array}$ & $\begin{array}{l}1.66 \\
0.68\end{array}$ \\
\hline Totals & 58 & & 1.39 & 27 & & .62 & 23 & & 1.51 & 5 & & 2.34 \\
\hline
\end{tabular}


$\Lambda \underline{E x}$

\begin{tabular}{|c|c|c|c|c|c|c|c|c|c|c|c|c|}
\hline \multirow{3}{*}{$\begin{array}{l}\text { Gate } \\
\text { No. }\end{array}$} & \multicolumn{11}{|c|}{ Days } & \\
\hline & \multicolumn{3}{|c|}{$1-4$} & \multicolumn{3}{|c|}{$5-8$} & \multicolumn{3}{|c|}{$9-12$} & \multicolumn{3}{|c|}{$13-16$} \\
\hline & Obs. & Exp. & $x^{2}$ & Obs. & Exp. & $x^{2}$ & Obs. & Exp. & $x^{2}$ & Obs. & Exp. & $x^{2}$ \\
\hline $\begin{array}{l}1 \\
2 \\
3 \\
4\end{array}$ & $\begin{array}{r}0 \\
0 \\
0 \\
16\end{array}$ & $\begin{array}{l}4.00 \\
4.00 \\
4.00 \\
4.00\end{array}$ & $\begin{array}{r}4.00 \\
4.00 \\
4.00 \\
36.00\end{array}$ & $\begin{array}{r}0 \\
0 \\
0 \\
17\end{array}$ & $\begin{array}{l}4.25 \\
4.25 \\
4.25 \\
4.25\end{array}$ & $\begin{array}{r}4.25 \\
4.25 \\
4.25 \\
38.25\end{array}$ & $\begin{array}{r}5 \\
5 \\
4 \\
34\end{array}$ & $\begin{array}{l}12.00 \\
12.00 \\
12.00 \\
12.00\end{array}$ & $\begin{array}{r}4.08 \\
4.08 \\
5.33 \\
40.33\end{array}$ & $\begin{array}{r}10 \\
9 \\
0 \\
13\end{array}$ & $\begin{array}{l}8.00 \\
8.00 \\
8.00 \\
8.00\end{array}$ & $\begin{array}{r}.50 \\
.13 \\
8.00 \\
3.13\end{array}$ \\
\hline Totals & 16 & & 48.00 & 17 & & 51.00 & 48 & & 53.82 & 32 & & 11.76 \\
\hline $\begin{array}{l}5 \\
6 \\
7 \\
8\end{array}$ & $\begin{array}{l}0 \\
2 \\
7 \\
6\end{array}$ & $\begin{array}{l}5.22 \\
2.16 \\
2.60 \\
5.03\end{array}$ & $\begin{array}{l}5.22 \\
0.01 \\
7.45 \\
0.19\end{array}$ & $\begin{array}{r}0 \\
0 \\
3 \\
13\end{array}$ & $\begin{array}{l}5.57 \\
2.30 \\
2.77 \\
5.36\end{array}$ & $\begin{array}{r}5.57 \\
2.30 \\
0.02 \\
10.89\end{array}$ & $\begin{array}{r}2 \\
10 \\
4 \\
17\end{array}$ & $\begin{array}{r}10.45 \\
5.96 \\
6.80 \\
9.71\end{array}$ & $\begin{array}{l}6.83 \\
2.74 \\
1.15 \\
5.47\end{array}$ & $\begin{array}{r}1 \\
4 \\
2 \\
13\end{array}$ & $\begin{array}{l}6.05 \\
4.72 \\
4.46 \\
4.75\end{array}$ & $\begin{array}{r}4.22 \\
0.11 \\
1.36 \\
14.33\end{array}$ \\
\hline Totals & 15 & & 12.86 & 16 & & 18.78 & 33 & & 16.19 & 20 & & 20.02 \\
\hline $\begin{array}{r}9 \\
10 \\
11 \\
12\end{array}$ & $\begin{array}{l}1 \\
1 \\
6 \\
2\end{array}$ & $\begin{array}{l}1.76 \\
2.62 \\
3.25 \\
2.37\end{array}$ & $\begin{array}{l}0.33 \\
1.00 \\
2.33 \\
0.06\end{array}$ & $\begin{array}{l}2 \\
2 \\
3 \\
8\end{array}$ & $\begin{array}{l}2.32 \\
2.39 \\
5.06 \\
5.24\end{array}$ & $\begin{array}{l}0.04 \\
0.06 \\
0.84 \\
1.45\end{array}$ & $\begin{array}{r}4 \\
5 \\
3 \\
15\end{array}$ & $\begin{array}{l}5.89 \\
6.26 \\
7.31 \\
7.53\end{array}$ & $\begin{array}{l}0.61 \\
0.25 \\
2.54 \\
7.41\end{array}$ & $\begin{array}{l}1 \\
3 \\
0 \\
3\end{array}$ & $\begin{array}{l}1.39 \\
1.38 \\
2.03 \\
2.20\end{array}$ & $\begin{array}{l}0.11 \\
1.90 \\
2.03 \\
0.29\end{array}$ \\
\hline Totals & 10 & & 3.72 & 15 & & 2.39 & 27 & & 10.81 & 7 & & 4.33 \\
\hline $\begin{array}{l}13 \\
14\end{array}$ & $\begin{array}{l}4 \\
1\end{array}$ & $\begin{array}{l}3.02 \\
1.98\end{array}$ & $\begin{array}{l}0.32 \\
0.49\end{array}$ & $\begin{array}{l}7 \\
5\end{array}$ & $\begin{array}{l}7.55 \\
4.44\end{array}$ & $\begin{array}{l}0.04 \\
0.07\end{array}$ & $\begin{array}{l}2 \\
9\end{array}$ & $\begin{array}{l}6.65 \\
4.34\end{array}$ & $\begin{array}{l}3.25 \\
5.00\end{array}$ & $\begin{array}{l}1 \\
1\end{array}$ & $\begin{array}{l}0.95 \\
1.05\end{array}$ & $\begin{array}{l}0.00 \\
0.00\end{array}$ \\
\hline Totals & 5 & & 0.81 & 12 & & 0.11 & 11 & & 8.25 & 2 & & 0.00 \\
\hline
\end{tabular}


I Ex

\begin{tabular}{|c|c|c|c|c|c|c|c|c|c|c|c|c|}
\hline \multirow{3}{*}{$\begin{array}{l}\text { Gate } \\
\text { No. }\end{array}$} & \multicolumn{11}{|c|}{ Days } & \\
\hline & \multicolumn{3}{|c|}{$1-4$} & \multicolumn{3}{|c|}{$5-8$} & \multicolumn{3}{|c|}{$9-12$} & \multicolumn{3}{|c|}{$13-16$} \\
\hline & Obs. & Exp. & $x^{2}$ & Obs. & Exp. & $x^{2}$ & Obs. & Exp. & $x^{2}$ & Obs. & Exp. & $x^{2}$ \\
\hline $\begin{array}{l}1 \\
2 \\
3 \\
4\end{array}$ & $\begin{array}{r}31 \\
25 \\
7 \\
55\end{array}$ & $\begin{array}{l}29.50 \\
29.50 \\
29.50 \\
29.50\end{array}$ & $\begin{array}{r}0.08 \\
0.69 \\
17.16 \\
22.04\end{array}$ & $\begin{array}{l}11 \\
39 \\
12 \\
43\end{array}$ & $\begin{array}{l}26.25 \\
26.25 \\
26.25 \\
26.25\end{array}$ & $\begin{array}{r}8.86 \\
6.19 \\
7.74 \\
10.69\end{array}$ & $\begin{array}{r}4 \\
72 \\
8 \\
30\end{array}$ & $\begin{array}{l}28.50 \\
28.50 \\
28.50 \\
28.50\end{array}$ & $\begin{array}{r}21.06 \\
66.39 \\
14.75 \\
0.08\end{array}$ & $\begin{array}{r}10 \\
24 \\
5 \\
12\end{array}$ & $\begin{array}{l}12.75 \\
12.75 \\
12.75 \\
12.75\end{array}$ & $\begin{array}{l}0.59 \\
9.93 \\
4.71 \\
0.04\end{array}$ \\
\hline Totals & 118 & & 39.97 & 105 & & 33.48 & 114 & & 102.28 & 51 & & 15.27 \\
\hline $\begin{array}{l}5 \\
6 \\
7 \\
8\end{array}$ & $\begin{array}{r}40 \\
27 \\
5 \\
44\end{array}$ & $\begin{array}{l}35.29 \\
25.47 \\
25.71 \\
29.42\end{array}$ & $\begin{array}{r}0.63 \\
0.09 \\
16.68 \\
7.23\end{array}$ & $\begin{array}{r}42 \\
15 \\
8 \\
37\end{array}$ & $\begin{array}{l}27.10 \\
23.90 \\
26.31 \\
24.56\end{array}$ & $\begin{array}{r}8.19 \\
3.31 \\
12.74 \\
6.30\end{array}$ & $\begin{array}{l}20 \\
65 \\
13 \\
19\end{array}$ & $\begin{array}{l}26.54 \\
32.09 \\
34.44 \\
23.77\end{array}$ & $\begin{array}{r}1.61 \\
33.75 \\
13.35 \\
0.96\end{array}$ & $\begin{array}{r}8 \\
25 \\
11 \\
5\end{array}$ & $\begin{array}{l}12.35 \\
12.93 \\
13.36 \\
10.29\end{array}$ & $\begin{array}{r}1.53 \\
11.27 \\
0.42 \\
2.72\end{array}$ \\
\hline Totals & 116 & & 24.63 & 102 & & 30.55 & 117 & & 49.67 & 49 & & 15.94 \\
\hline $\begin{array}{r}9 \\
10 \\
11 \\
12\end{array}$ & $\begin{array}{r}12 \\
30 \\
9 \\
63\end{array}$ & $\begin{array}{l}30.64 \\
22.57 \\
26.15 \\
34.64\end{array}$ & $\begin{array}{r}11.34 \\
2.45 \\
11.25 \\
23.22\end{array}$ & $\begin{array}{r}27 \\
14 \\
3 \\
55\end{array}$ & $\begin{array}{l}26.60 \\
18.04 \\
23.15 \\
31.18\end{array}$ & $\begin{array}{r}0.01 \\
0.90 \\
17.54 \\
18.20\end{array}$ & $\begin{array}{r}28 \\
52 \\
4 \\
27\end{array}$ & $\begin{array}{l}31.59 \\
33.77 \\
22.91 \\
23.68\end{array}$ & $\begin{array}{r}0.41 \\
9.84 \\
15.61 \\
0.47\end{array}$ & $\begin{array}{r}7 \\
22 \\
9 \\
9\end{array}$ & $\begin{array}{r}12.91 \\
14.89 \\
10.34 \\
8.78\end{array}$ & $\begin{array}{l}2.71 \\
3.42 \\
0.17 \\
0.01\end{array}$ \\
\hline Totals & 114 & & 48.26 & 99 & & 36.65 & 111 & & 26.32 & 47 & & 6.31 \\
\hline $\begin{array}{l}13 \\
14\end{array}$ & $\begin{array}{l}39 \\
50\end{array}$ & $\begin{array}{l}51.78 \\
37.18\end{array}$ & $\begin{array}{l}3.15 \\
4.42\end{array}$ & $\begin{array}{l}43 \\
20\end{array}$ & $\begin{array}{l}37.01 \\
25.97\end{array}$ & $\begin{array}{l}0.97 \\
1.37\end{array}$ & $\begin{array}{l}43 \\
27\end{array}$ & $\begin{array}{l}27.88 \\
42.03\end{array}$ & $\begin{array}{l}8.20 \\
5.37\end{array}$ & $\begin{array}{l}22 \\
12\end{array}$ & $\begin{array}{l}14.32 \\
19.63\end{array}$ & $\begin{array}{l}4.12 \\
2.97\end{array}$ \\
\hline Totals & 89 & & 7.57 & 63 & & 2.34 & 70 & & 13.57 & 34 & & 7.09 \\
\hline
\end{tabular}


$\Delta \underline{\text { In }}$

\begin{tabular}{|c|c|c|c|c|c|c|c|c|c|c|c|c|}
\hline \multirow{3}{*}{$\begin{array}{c}\text { Gate } \\
\text { No. }\end{array}$} & \multicolumn{12}{|c|}{ Days } \\
\hline & \multicolumn{3}{|c|}{$1-4$} & \multicolumn{3}{|c|}{$5-8$} & \multicolumn{3}{|c|}{$9-12$} & \multicolumn{3}{|c|}{$13-16$} \\
\hline & Obs. & Exp. & $x^{2}$ & Obs. & Exp. & $\mathrm{x}^{2}$ & Obs. & Exp. & $x^{2}$ & Obs. & Exp. & $x^{2}$ \\
\hline $\begin{array}{l}1 \\
2 \\
3 \\
4\end{array}$ & $\begin{array}{r}1 \\
22 \\
8 \\
4\end{array}$ & $\begin{array}{l}7.58 \\
9.42 \\
9.46 \\
8.51\end{array}$ & $\begin{array}{r}5.71 \\
16.80 \\
0.23 \\
2.39\end{array}$ & $\begin{array}{r}3 \\
30 \\
5 \\
0\end{array}$ & $\begin{array}{r}9.22 \\
11.11 \\
9.19 \\
8.41\end{array}$ & $\begin{array}{r}4.19 \\
32.12 \\
1.91 \\
8.41\end{array}$ & $\begin{array}{r}5 \\
33 \\
5 \\
2\end{array}$ & $\begin{array}{r}10.58 \\
14.04 \\
11.27 \\
9.13\end{array}$ & $\begin{array}{r}2.94 \\
26.60 \\
3.49 \\
5.57\end{array}$ & $\begin{array}{r}1 \\
52 \\
1 \\
0\end{array}$ & $\begin{array}{r}11.91 \\
18.32 \\
14.36 \\
9.39\end{array}$ & $\begin{array}{r}9.99 \\
61.92 \\
12.43 \\
9.39\end{array}$ \\
\hline Totals & 35 & & 25.13 & 38 & & 46.63 & 45 & & 38.60 & 54 & & 93.73 \\
\hline $\begin{array}{l}5 \\
6 \\
7 \\
8\end{array}$ & $\begin{array}{r}2 \\
7 \\
10 \\
10\end{array}$ & $\begin{array}{l}6.84 \\
7.58 \\
7.12 \\
7.48\end{array}$ & $\begin{array}{l}3.42 \\
0.04 \\
1.16 \\
0.85\end{array}$ & $\begin{array}{r}4 \\
13 \\
7 \\
6\end{array}$ & $\begin{array}{l}7.40 \\
8.43 \\
7.18 \\
6.97\end{array}$ & $\begin{array}{l}1.56 \\
2.48 \\
0.01 \\
0.13\end{array}$ & $\begin{array}{r}3 \\
18 \\
12 \\
6\end{array}$ & $\begin{array}{r}10.07 \\
10.16 \\
9.07 \\
9.64\end{array}$ & $\begin{array}{l}4.96 \\
6.05 \\
0.95 \\
1.37\end{array}$ & $\begin{array}{r}0 \\
25 \\
24 \\
4\end{array}$ & $\begin{array}{r}10.20 \\
18.83 \\
14.91 \\
9.05\end{array}$ & $\begin{array}{r}10.20 \\
2.02 \\
5.54 \\
2.82\end{array}$ \\
\hline Totals & 29 & & 5.47 & 30 & & 4.18 & 39 & & 13.33 & 53 & & 20.58 \\
\hline $\begin{array}{r}9 \\
10 \\
11 \\
12\end{array}$ & $\begin{array}{l}4 \\
9 \\
5 \\
8\end{array}$ & $\begin{array}{l}4.98 \\
5.80 \\
5.96 \\
9.25\end{array}$ & $\begin{array}{l}0.19 \\
1.77 \\
0.15 \\
0.17\end{array}$ & $\begin{array}{l}8 \\
9 \\
5 \\
6\end{array}$ & $\begin{array}{l}5.73 \\
7.52 \\
6.06 \\
8.68\end{array}$ & $\begin{array}{l}0.90 \\
0.29 \\
0.19 \\
0.83\end{array}$ & $\begin{array}{r}12 \\
8 \\
9 \\
8\end{array}$ & $\begin{array}{r}7.96 \\
11.29 \\
7.61 \\
10.12\end{array}$ & $\begin{array}{l}2.05 \\
0.96 \\
0.25 \\
0.44\end{array}$ & $\begin{array}{r}8 \\
31 \\
2 \\
5\end{array}$ & $\begin{array}{r}9.42 \\
12.41 \\
9.94 \\
14.21\end{array}$ & $\begin{array}{r}0.21 \\
27.85 \\
6.34 \\
5.97\end{array}$ \\
\hline Totals & 26 & & 2.28 & 28 & & 2.21 & 37 & & 3.70 & 46 & & 34.37 \\
\hline $\begin{array}{l}13 \\
14\end{array}$ & $\begin{array}{r}17 \\
8\end{array}$ & & & $\begin{array}{l}15 \\
12\end{array}$ & & & $\begin{array}{l}16 \\
19\end{array}$ & & & $\begin{array}{l}21 \\
17\end{array}$ & & \\
\hline Totals & 25 & & & 27 & & & 35 & & & 38 & & \\
\hline
\end{tabular}


$\mathrm{Z}$ In

\begin{tabular}{|c|c|c|c|c|c|c|c|c|c|c|c|c|}
\hline \multirow{3}{*}{$\begin{array}{l}\text { Gate } \\
\text { No. }\end{array}$} & \multicolumn{11}{|c|}{ Days } & \\
\hline & \multicolumn{3}{|c|}{$1-4$} & \multicolumn{3}{|c|}{$5-8$} & \multicolumn{3}{|c|}{$9-12$} & \multicolumn{3}{|c|}{$13-16$} \\
\hline & Obs. & Exp. & $x^{2}$ & Obs. & Exp. & $x^{2}$ & Obs. & Exp. & $\mathrm{X}^{2}$ & Obs. & Exp. & $\mathrm{x}^{2}$ \\
\hline $\begin{array}{l}1 \\
2 \\
3 \\
4\end{array}$ & $\begin{array}{r}6 \\
3 \\
11 \\
162\end{array}$ & $\begin{array}{l}41.82 \\
36.35 \\
45.99 \\
57.89\end{array}$ & $\begin{array}{r}30.68 \\
30.60 \\
26.62 \\
187.23\end{array}$ & $\begin{array}{r}13 \\
1 \\
8 \\
50\end{array}$ & $\begin{array}{l}17.34 \\
17.70 \\
17.37 \\
19.46\end{array}$ & $\begin{array}{r}1.09 \\
15.76 \\
5.05 \\
47.93\end{array}$ & $\begin{array}{r}11 \\
3 \\
1 \\
58\end{array}$ & $\begin{array}{l}15.69 \\
15.71 \\
19.64 \\
21.86\end{array}$ & $\begin{array}{r}1.40 \\
10.34 \\
17.69 \\
59.75\end{array}$ & $\begin{array}{r}1 \\
1 \\
0 \\
43\end{array}$ & $\begin{array}{r}9.72 \\
10.59 \\
12.07 \\
12.59\end{array}$ & $\begin{array}{r}7.82 \\
8.68 \\
12.07 \\
73.45\end{array}$ \\
\hline Totals & 182 & & 275.13 & 72 & & 69.83 & 73 & & 89.18 & 45 & & 102.02 \\
\hline $\begin{array}{l}5 \\
6 \\
7 \\
8\end{array}$ & $\begin{array}{r}19 \\
33 \\
4 \\
120\end{array}$ & $\begin{array}{l}40.57 \\
34.60 \\
48.24 \\
52.50\end{array}$ & $\begin{array}{r}11.47 \\
0.07 \\
40.57 \\
86.79\end{array}$ & $\begin{array}{r}9 \\
25 \\
6 \\
32\end{array}$ & $\begin{array}{l}18.89 \\
14.38 \\
16.64 \\
22.08\end{array}$ & $\begin{array}{l}5.18 \\
7.84 \\
6.90 \\
4.46\end{array}$ & $\begin{array}{r}4 \\
11 \\
12 \\
46\end{array}$ & $\begin{array}{l}19.75 \\
15.10 \\
15.70 \\
22.48\end{array}$ & $\begin{array}{r}12.56 \\
1.11 \\
0.87 \\
24.61\end{array}$ & $\begin{array}{r}2 \\
9 \\
9 \\
24\end{array}$ & $\begin{array}{r}10.35 \\
9.90 \\
10.98 \\
12.77\end{array}$ & $\begin{array}{l}6.74 \\
0.08 \\
0.36 \\
9.88\end{array}$ \\
\hline Totals & 176 & & 138.90 & 72 & & 24.28 & 73 & & 39.15 & 44 & & 17.06 \\
\hline $\begin{array}{r}9 \\
10 \\
11 \\
12\end{array}$ & $\begin{array}{r}32 \\
6 \\
88 \\
25\end{array}$ & $\begin{array}{l}32.18 \\
44.92 \\
31.42 \\
42.48\end{array}$ & $\begin{array}{r}0.00 \\
33.72 \\
101.89 \\
7.19\end{array}$ & $\begin{array}{r}14 \\
5 \\
25 \\
23\end{array}$ & $\begin{array}{l}13.70 \\
18.00 \\
14.49 \\
20.78\end{array}$ & $\begin{array}{l}0.01 \\
9.39 \\
7.62 \\
0.24\end{array}$ & $\begin{array}{r}11 \\
9 \\
16 \\
28\end{array}$ & $\begin{array}{l}13.91 \\
20.08 \\
13.02 \\
16.97\end{array}$ & $\begin{array}{l}0.61 \\
6.11 \\
0.68 \\
7.17\end{array}$ & $\begin{array}{r}4 \\
10 \\
12 \\
14\end{array}$ & $\begin{array}{r}8.86 \\
13.16 \\
7.97 \\
10.00\end{array}$ & $\begin{array}{l}2.67 \\
0.76 \\
2.04 \\
1.60\end{array}$ \\
\hline Totals & 151 & & 142.80 & 67 & & 17.26 & 64 & & 14.51 & 40 & & 7.07 \\
\hline $\begin{array}{l}13 \\
14\end{array}$ & $\begin{array}{l}32 \\
35\end{array}$ & & & $\begin{array}{l}20 \\
16\end{array}$ & & & $\begin{array}{l}23 \\
30\end{array}$ & & & $\begin{array}{l}11 \\
17\end{array}$ & & \\
\hline Totals & 67 & & & 36 & & & 53 & & & 28 & & \\
\hline
\end{tabular}


$\mathrm{K}$ In

\begin{tabular}{|c|c|c|c|c|c|c|c|c|c|c|c|c|}
\hline \multirow{3}{*}{$\begin{array}{c}\text { Gate } \\
\text { No. }\end{array}$} & \multicolumn{11}{|c|}{ Days } & \\
\hline & \multicolumn{3}{|c|}{$1-4$} & \multicolumn{3}{|c|}{$5-8$} & \multicolumn{3}{|c|}{$9-12$} & \multicolumn{3}{|c|}{$13-16$} \\
\hline & Obs. & Exp. & $x^{2}$ & Obs. & Exp. & $x^{2}$ & Obs. & Exp. & $x^{2}$ & Obs. & Exp. & $x^{2}$ \\
\hline $\begin{array}{l}1 \\
2 \\
3 \\
4\end{array}$ & $\begin{array}{l}29 \\
41 \\
16 \\
45\end{array}$ & $\begin{array}{l}34.85 \\
31.65 \\
29.23 \\
35.08\end{array}$ & $\begin{array}{l}0.98 \\
2.76 \\
5.99 \\
2.89\end{array}$ & $\begin{array}{r}22 \\
28 \\
5 \\
17\end{array}$ & $\begin{array}{l}17.96 \\
18.94 \\
17.20 \\
17.92\end{array}$ & $\begin{array}{l}0.91 \\
4.33 \\
8.65 \\
0.05\end{array}$ & $\begin{array}{r}13 \\
8 \\
10 \\
25\end{array}$ & $\begin{array}{r}13.65 \\
16.20 \\
13.54 \\
.12 .56\end{array}$ & $\begin{array}{r}0.03 \\
4.15 \\
0.93 \\
12.32\end{array}$ & $\begin{array}{r}11 \\
18 \\
3 \\
4\end{array}$ & $\begin{array}{r}8.54 \\
10.57 \\
8.96 \\
7.92\end{array}$ & $\begin{array}{l}0.71 \\
5.22 \\
3.96 \\
1.94\end{array}$ \\
\hline Totals & 131 & & 12.62 & 72 & & 13.94 & 56 & & 17.43 & 36 & & 11.83 \\
\hline $\begin{array}{l}5 \\
6 \\
7 \\
8\end{array}$ & $\begin{array}{l}48 \\
31 \\
19 \\
25\end{array}$ & $\begin{array}{l}35.44 \\
35.52 \\
25.33 \\
26.73\end{array}$ & $\begin{array}{l}4.45 \\
0.58 \\
1.58 \\
0.11\end{array}$ & $\begin{array}{l}17 \\
20 \\
15 \\
15\end{array}$ & $\begin{array}{l}14.55 \\
19.14 \\
18.15 \\
15.20\end{array}$ & $\begin{array}{l}0.41 \\
0.04 \\
0.55 \\
0.00\end{array}$ & $\begin{array}{r}7 \\
19 \\
11 \\
9\end{array}$ & $\begin{array}{l}10.48 \\
12.95 \\
11.62 \\
10.73\end{array}$ & $\begin{array}{l}1.16 \\
2.83 \\
0.03 \\
0.28\end{array}$ & $\begin{array}{r}3 \\
10 \\
7 \\
5\end{array}$ & $\begin{array}{l}5.01 \\
7.39 \\
7.17 \\
5.42\end{array}$ & $\begin{array}{l}0.81 \\
0.92 \\
0.00 \\
0.03\end{array}$ \\
\hline Totals & 123 & & 6.72 & 67 & & 1.00 & 46 & & 4.30 & 25 & & 1.76 \\
\hline $\begin{array}{r}9 \\
10 \\
11 \\
12\end{array}$ & $\begin{array}{l}55 \\
21 \\
15 \\
18\end{array}$ & $\begin{array}{l}21.99 \\
28.25 \\
23.87 \\
34.84\end{array}$ & $\begin{array}{r}49.55 \\
1.86 \\
3.30 \\
8.14\end{array}$ & $\begin{array}{r}14 \\
24 \\
17 \\
9\end{array}$ & $\begin{array}{l}12.24 \\
14.23 \\
14.69 \\
22.82\end{array}$ & $\begin{array}{l}0.25 \\
6.71 \\
0.36 \\
8.37\end{array}$ & $\begin{array}{r}9 \\
15 \\
9 \\
8\end{array}$ & $\begin{array}{r}8.13 \\
10.12 \\
9.10 \\
13.61\end{array}$ & $\begin{array}{l}0.09 \\
2.35 \\
0.00 \\
2.31\end{array}$ & $\begin{array}{l}4 \\
9 \\
6 \\
2\end{array}$ & $\begin{array}{l}4.04 \\
4.78 \\
4.79 \\
7.37\end{array}$ & $\begin{array}{l}0.00 \\
3.73 \\
0.30 \\
3.91\end{array}$ \\
\hline Totals & 109 & & 62.85 & 64 & & 15.69 & 41 & & 4.74 & 21 & & 7.94 \\
\hline $\begin{array}{l}13 \\
14\end{array}$ & $\begin{array}{l}32 \\
23\end{array}$ & & & $\begin{array}{r}15 \\
7\end{array}$ & & & $\begin{array}{l}16 \\
10\end{array}$ & & & $\begin{array}{l}4 \\
2\end{array}$ & & \\
\hline Totals & 55 & & & 22 & & & 26 & & & 6 & & \\
\hline
\end{tabular}


$\Lambda$ In

\begin{tabular}{|c|c|c|c|c|c|c|c|c|c|c|c|c|}
\hline \multirow{3}{*}{$\begin{array}{l}\text { Gate } \\
\text { No. }\end{array}$} & \multicolumn{11}{|c|}{ Days } & \\
\hline & \multicolumn{3}{|c|}{$1-4$} & \multicolumn{3}{|c|}{$5-8$} & \multicolumn{3}{|c|}{$9-12$} & \multicolumn{3}{|c|}{$13-16$} \\
\hline & Obs. & Exp. & $x^{2}$ & Obs. & Exp. & $\mathrm{x}^{2}$ & Obs. & Exp. & $\mathrm{X}^{2}$ & Obs. & Exp. & $\mathrm{x}^{2}$ \\
\hline $\begin{array}{l}1 \\
2 \\
3 \\
4\end{array}$ & $\begin{array}{l}1 \\
7 \\
1 \\
7\end{array}$ & $\begin{array}{l}3.25 \\
2.86 \\
4.45 \\
5.37\end{array}$ & $\begin{array}{l}1.58 \\
5.99 \\
2.67 \\
0.49\end{array}$ & $\begin{array}{r}0 \\
0 \\
0 \\
17\end{array}$ & $\begin{array}{l}3.74 \\
3.07 \\
4.45 \\
5.74\end{array}$ & $\begin{array}{r}3.74 \\
3.07 \\
4.45 \\
22.09\end{array}$ & $\begin{array}{r}5 \\
12 \\
0 \\
31\end{array}$ & $\begin{array}{l}11.02 \\
11.54 \\
12.06 \\
13.39\end{array}$ & $\begin{array}{r}3.29 \\
0.02 \\
12.06 \\
23.16\end{array}$ & $\begin{array}{r}9 \\
5 \\
2 \\
16\end{array}$ & $\begin{array}{l}7.41 \\
6.83 \\
8.07 \\
9.64\end{array}$ & $\begin{array}{l}0.34 \\
0.49 \\
4.57 \\
4.20\end{array}$ \\
\hline Totals & 16 & & 10.73 & 17 & & 33.35 & 48 & & 38.53 & 32 & & 9.60 \\
\hline $\begin{array}{l}5 \\
6 \\
7 \\
8\end{array}$ & $\begin{array}{r}1 \\
0 \\
2 \\
11\end{array}$ & $\begin{array}{l}4.23 \\
3.62 \\
2.87 \\
3.28\end{array}$ & $\begin{array}{r}2.47 \\
3.62 \\
0.26 \\
18.17\end{array}$ & $\begin{array}{r}1 \\
2 \\
0 \\
13\end{array}$ & $\begin{array}{l}4.50 \\
5.24 \\
3.38 \\
2.85\end{array}$ & $\begin{array}{r}2.72 \\
2.00 \\
3.38 \\
36.15\end{array}$ & $\begin{array}{r}1 \\
11 \\
2 \\
18\end{array}$ & $\begin{array}{l}8.45 \\
7.83 \\
7.27 \\
8.43\end{array}$ & $\begin{array}{r}6.57 \\
1.28 \\
3.82 \\
10.86\end{array}$ & $\begin{array}{r}3 \\
4 \\
2 \\
12\end{array}$ & $\begin{array}{l}4.97 \\
6.09 \\
5.24 \\
4.69\end{array}$ & $\begin{array}{r}0.78 \\
0.72 \\
2.00 \\
11.39\end{array}$ \\
\hline Totals & 14 & & 24.52 & 16 & & 44.25 & 32 & & 22.53 & 21 & & 14.89 \\
\hline $\begin{array}{r}9 \\
10 \\
11 \\
12\end{array}$ & $\begin{array}{l}6 \\
0 \\
3 \\
1\end{array}$ & $\begin{array}{l}2.21 \\
3.26 \\
2.00 \\
2.53\end{array}$ & $\begin{array}{l}6.50 \\
3.26 \\
0.50 \\
0.93\end{array}$ & $\begin{array}{l}8 \\
4 \\
1 \\
1\end{array}$ & $\begin{array}{l}2.82 \\
3.62 \\
3.07 \\
4.48\end{array}$ & $\begin{array}{l}9.52 \\
0.04 \\
1.40 \\
2.70\end{array}$ & $\begin{array}{l}7 \\
4 \\
6 \\
6\end{array}$ & $\begin{array}{l}5.05 \\
7.40 \\
4.63 \\
5.91\end{array}$ & $\begin{array}{l}0.75 \\
1.56 \\
0.41 \\
0.00\end{array}$ & $\begin{array}{l}3 \\
4 \\
2 \\
2\end{array}$ & $\begin{array}{l}2.17 \\
2.68 \\
2.46 \\
3.69\end{array}$ & $\begin{array}{l}0.32 \\
0.65 \\
0.09 \\
0.77\end{array}$ \\
\hline Totals & 10 & & 11.19 & 15 & & 13.66 & 27 & & 2.72 & 13 & & 1.83 \\
\hline $\begin{array}{l}13 \\
14\end{array}$ & $\begin{array}{l}2 \\
3\end{array}$ & & & $\begin{array}{l}7 \\
5\end{array}$ & & & $\begin{array}{r}7 \\
10\end{array}$ & & & $\begin{array}{l}5 \\
3\end{array}$ & & \\
\hline Totals & 5 & & & 12 & & & 17 & & & 8 & & \\
\hline
\end{tabular}


I In

\begin{tabular}{|c|c|c|c|c|c|c|c|c|c|c|c|c|}
\hline \multirow{3}{*}{$\begin{array}{c}\text { Gate } \\
\text { No. }\end{array}$} & \multicolumn{11}{|c|}{ Days } & \\
\hline & \multicolumn{3}{|c|}{$1-4$} & \multicolumn{3}{|c|}{$5-8$} & \multicolumn{3}{|c|}{$9-12$} & \multicolumn{3}{|c|}{$13-16$} \\
\hline & Obs. & Exp. & $x^{2}$ & Obs. & Exp. & $x^{2}$ & Obs. & Exp. & $x^{2}$ & Obs. & Exp. & $\mathrm{X}^{2}$ \\
\hline $\begin{array}{l}1 \\
2 \\
3 \\
4\end{array}$ & $\begin{array}{r}24 \\
28 \\
2 \\
61\end{array}$ & $\begin{array}{l}28.06 \\
28.99 \\
28.36 \\
29.62\end{array}$ & $\begin{array}{r}0.59 \\
0.03 \\
24.50 \\
33.24\end{array}$ & $\begin{array}{r}7 \\
41 \\
7 \\
50\end{array}$ & $\begin{array}{l}23.95 \\
26.85 \\
27.28 \\
26.86\end{array}$ & $\begin{array}{r}12.00 \\
7.46 \\
15.08 \\
19.94\end{array}$ & $\begin{array}{r}5 \\
73 \\
5 \\
32\end{array}$ & $\begin{array}{l}25.04 \\
30.46 \\
30.67 \\
28.64\end{array}$ & $\begin{array}{r}16.04 \\
59.41 \\
21.49 \\
0.39\end{array}$ & $\begin{array}{r}5 \\
23 \\
3 \\
20\end{array}$ & $\begin{array}{l}11.31 \\
11.83 \\
13.42 \\
14.45\end{array}$ & $\begin{array}{r}3.52 \\
10.46 \\
8.09 \\
2.13\end{array}$ \\
\hline Totals & 115 & & 58.36 & 105 & & 54.48 & 114 & & 97.33 & 51 & & 24.20 \\
\hline $\begin{array}{l}5 \\
6 \\
7 \\
8\end{array}$ & $\begin{array}{l}32 \\
23 \\
32 \\
27\end{array}$ & $\begin{array}{l}31.19 \\
26.76 \\
24.28 \\
31.58\end{array}$ & $\begin{array}{l}0.02 \\
0.53 \\
2.45 \\
0.66\end{array}$ & $\begin{array}{l}16 \\
22 \\
30 \\
34\end{array}$ & $\begin{array}{l}28.24 \\
21.21 \\
21.64 \\
30.90\end{array}$ & $\begin{array}{l}5.31 \\
0.03 \\
3.23 \\
0.31\end{array}$ & $\begin{array}{r}4 \\
32 \\
31 \\
46\end{array}$ & $\begin{array}{l}28.94 \\
21.03 \\
25.62 \\
37.53\end{array}$ & $\begin{array}{r}21.49 \\
5.72 \\
1.13 \\
1.91\end{array}$ & $\begin{array}{r}4 \\
10 \\
9 \\
26\end{array}$ & $\begin{array}{r}13.74 \\
8.77 \\
9.68 \\
16.79\end{array}$ & $\begin{array}{l}6.90 \\
0.17 \\
0.05 \\
5.05\end{array}$ \\
\hline Totals & 114 & & 3.66 & 102 & & 8.88 & 113 & & 30.25 & 49 & & 12.17 \\
\hline $\begin{array}{r}9 \\
10 \\
11 \\
12\end{array}$ & $\begin{array}{l}30 \\
19 \\
23 \\
39\end{array}$ & $\begin{array}{l}25.16 \\
38.47 \\
21.55 \\
25.77\end{array}$ & $\begin{array}{l}0.93 \\
9.85 \\
0.10 \\
6.79\end{array}$ & $\begin{array}{l}23 \\
10 \\
27 \\
40\end{array}$ & $\begin{array}{l}20.53 \\
27.17 \\
21.55 \\
30.71\end{array}$ & $\begin{array}{r}0.30 \\
10.85 \\
1.38 \\
2.81\end{array}$ & $\begin{array}{r}5 \\
17 \\
32 \\
55\end{array}$ & $\begin{array}{l}21.39 \\
26.12 \\
24.48 \\
36.97\end{array}$ & $\begin{array}{r}12.56 \\
3.18 \\
2.31 \\
8.79\end{array}$ & $\begin{array}{r}3 \\
6 \\
9 \\
28\end{array}$ & $\begin{array}{r}9.30 \\
11.97 \\
10.06 \\
14.66\end{array}$ & $\begin{array}{r}4.27 \\
2.98 \\
0.11 \\
12.14\end{array}$ \\
\hline Totals & 111 & & 17.67 & 100 & & 15.34 & 109 & & 26.84 & 46 & & 19.50 \\
\hline $\begin{array}{l}13 \\
14\end{array}$ & $\begin{array}{l}29 \\
55\end{array}$ & & & $\begin{array}{l}23 \\
19\end{array}$ & & & $\begin{array}{l}33 \\
19\end{array}$ & & & $\begin{array}{r}11 \\
8\end{array}$ & & \\
\hline Totals & 84 & & & 42 & & & 52 & & & 19 & & \\
\hline
\end{tabular}


$\Delta$ Inter

\begin{tabular}{|c|c|c|c|c|c|c|c|c|c|c|c|c|}
\hline \multirow{3}{*}{$\begin{array}{c}\text { Gate } \\
\text { No. }\end{array}$} & \multicolumn{11}{|c|}{ Days } & \\
\hline & \multicolumn{3}{|c|}{$1-4$} & \multicolumn{3}{|c|}{$5-8$} & \multicolumn{3}{|c|}{$9-12$} & \multicolumn{3}{|c|}{$13-16$} \\
\hline & Obs. & Exp. & $x^{2}$ & Obs. & Exp. & $x^{2}$ & Obs. & Exp. & $x^{2}$ & Obs. & Exp. & $x^{2}$ \\
\hline $\begin{array}{l}5 \\
6 \\
7 \\
8\end{array}$ & $\begin{array}{l}0 \\
0 \\
0 \\
2\end{array}$ & $\begin{array}{l}0.50 \\
0.50 \\
0.50 \\
0.50\end{array}$ & $\begin{array}{l}0.50 \\
0.50 \\
0.50 \\
4.50\end{array}$ & $\begin{array}{l}1 \\
0 \\
0 \\
0\end{array}$ & $\begin{array}{l}0.25 \\
0.25 \\
0.25 \\
0.25\end{array}$ & $\begin{array}{l}2.25 \\
0.25 \\
0.25 \\
0.25\end{array}$ & $\begin{array}{l}1 \\
1 \\
0 \\
1\end{array}$ & $\begin{array}{l}0.75 \\
0.75 \\
0.75 \\
0.75\end{array}$ & $\begin{array}{l}0.08 \\
0.08 \\
0.75 \\
0.08\end{array}$ & $\begin{array}{l}0 \\
0 \\
0 \\
0\end{array}$ & $\begin{array}{l}0.00 \\
0.00 \\
0.00 \\
0.00\end{array}$ & $\begin{array}{l}0.00 \\
0.00 \\
0.00 \\
0.00\end{array}$ \\
\hline Totals & 2 & & 6.00 & 1 & & 3.00 & 3 & & 0.99 & 0 & & 0.00 \\
\hline $\begin{array}{r}5 \\
6 \\
7 \\
8 \\
9 \\
10 \\
11 \\
12\end{array}$ & $\begin{array}{l}0 \\
0 \\
1 \\
1 \\
1 \\
1 \\
4 \\
3\end{array}$ & $\begin{array}{l}1.38 \\
1.38 \\
1.38 \\
1.38 \\
1.38 \\
1.38 \\
1.38 \\
1.38\end{array}$ & $\begin{array}{l}1.38 \\
1.38 \\
0.10 \\
0.10 \\
0.10 \\
0.10 \\
4.97 \\
1.90\end{array}$ & $\begin{array}{l}0 \\
1 \\
0 \\
0 \\
0 \\
2 \\
1 \\
1\end{array}$ & $\begin{array}{l}0.63 \\
0.63 \\
0.63 \\
0.63 \\
0.63 \\
0.63 \\
0.63 \\
0.63\end{array}$ & $\begin{array}{l}0.63 \\
0.22 \\
0.63 \\
0.63 \\
0.63 \\
2.98 \\
0.22 \\
0.22\end{array}$ & $\begin{array}{l}0 \\
1 \\
1 \\
1 \\
0 \\
3 \\
0 \\
4\end{array}$ & $\begin{array}{l}1.25 \\
1.25 \\
1.25 \\
1.25 \\
1.25 \\
1.25 \\
1.25 \\
1.25\end{array}$ & $\begin{array}{l}1.25 \\
0.05 \\
0.05 \\
0.05 \\
1.25 \\
2.45 \\
1.25 \\
6.05\end{array}$ & $\begin{array}{l}0 \\
0 \\
0 \\
0 \\
0 \\
2 \\
1 \\
0\end{array}$ & $\begin{array}{l}0.38 \\
0.38 \\
0.38 \\
0.38 \\
0.38 \\
0.38 \\
0.38 \\
0.38\end{array}$ & $\begin{array}{l}0.38 \\
0.38 \\
0.38 \\
0.38 \\
0.38 \\
6.91 \\
1.01 \\
0.38\end{array}$ \\
\hline Totals & 11 & & 10.03 & 5 & & 6.16 & 10 & & 12.40 & 3 & & 10.20 \\
\hline $\begin{array}{l}9 \\
10 \\
11 \\
12 \\
13 \\
14\end{array}$ & $\begin{array}{l}2 \\
1 \\
4 \\
6 \\
8 \\
8\end{array}$ & $\begin{array}{l}4.83 \\
4.83 \\
4.83 \\
4.83 \\
4.83 \\
4.83\end{array}$ & $\begin{array}{l}1.66 \\
3.04 \\
0.14 \\
0.28 \\
2.08 \\
2.08\end{array}$ & $\begin{array}{r}3 \\
0 \\
0 \\
2 \\
10 \\
10\end{array}$ & $\begin{array}{l}4.17 \\
4.17 \\
4.17 \\
4.17 \\
4.17 \\
4.17\end{array}$ & $\begin{array}{l}0.33 \\
4.17 \\
4.17 \\
1.13 \\
8.15 \\
8.15\end{array}$ & $\begin{array}{r}3 \\
2 \\
2 \\
1 \\
12 \\
15\end{array}$ & $\begin{array}{l}5.83 \\
5.83 \\
5.83 \\
5.83 \\
5.83 \\
5.83\end{array}$ & $\begin{array}{r}1.37 \\
2.52 \\
2.52 \\
4.00 \\
6.53 \\
14.42\end{array}$ & $\begin{array}{l}1 \\
1 \\
0 \\
1 \\
2 \\
4\end{array}$ & $\begin{array}{l}1.50 \\
1.50 \\
1.50 \\
1.50 \\
1.50 \\
1.50\end{array}$ & $\begin{array}{l}0.17 \\
0.17 \\
1.50 \\
0.17 \\
0.17 \\
4.17\end{array}$ \\
\hline Totals & 29 & & 9.28 & 25 & & 26.10 & 35 & & 31.36 & 9 & & 6.35 \\
\hline
\end{tabular}


$\mathrm{Z}$ Inter

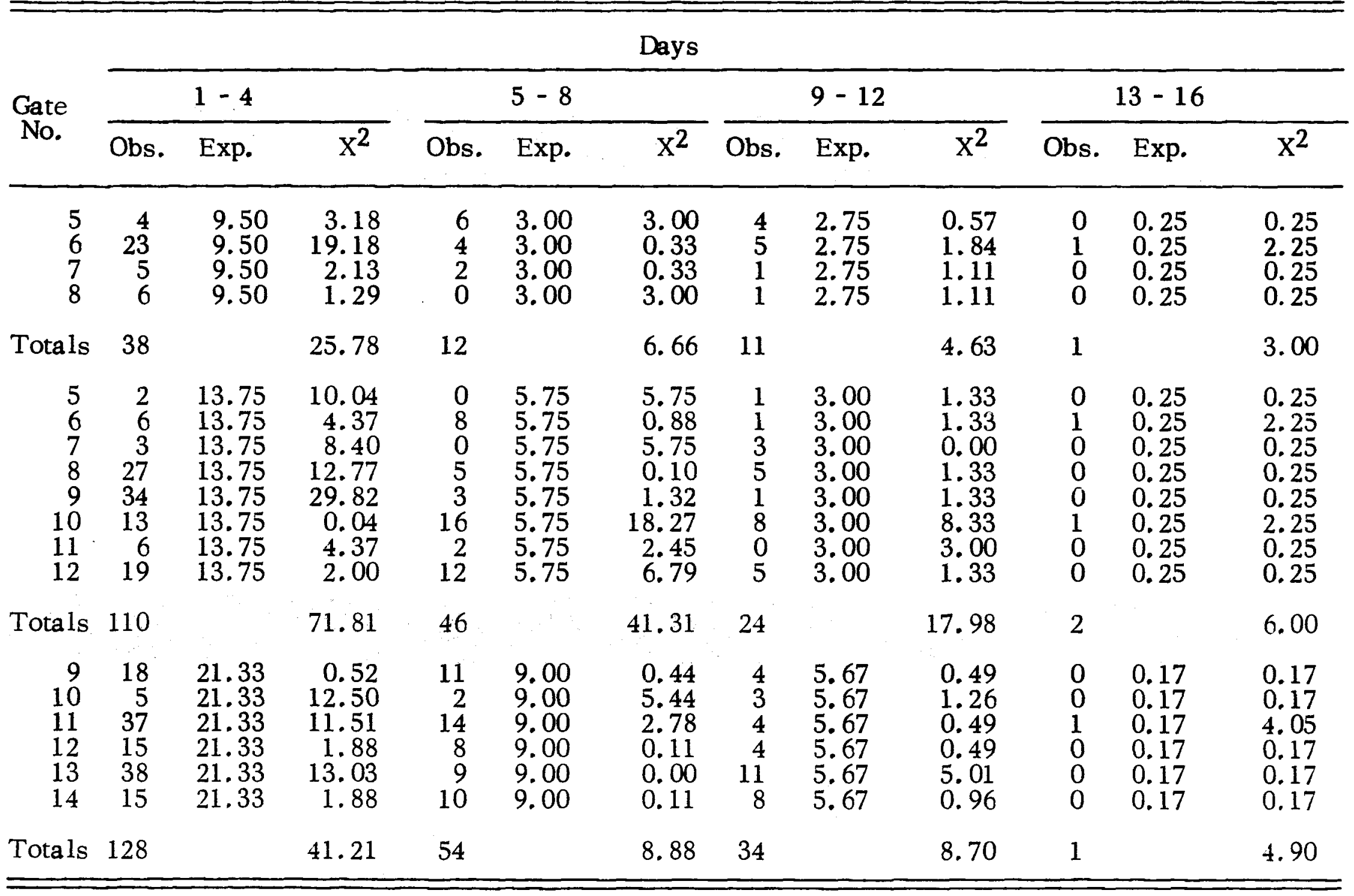


K Inter

\begin{tabular}{|c|c|c|c|c|c|c|c|c|c|c|c|c|}
\hline \multirow{3}{*}{$\begin{array}{l}\text { Gate } \\
\text { No. }\end{array}$} & \multicolumn{11}{|c|}{ Days } & \\
\hline & \multicolumn{3}{|c|}{$1-4$} & \multicolumn{3}{|c|}{$5-8$} & \multicolumn{3}{|c|}{$9-12$} & \multicolumn{3}{|c|}{$13-16$} \\
\hline & Obs. & Exp. & $\overline{x^{2}}$ & Obs. & Exp. & $\mathrm{x}^{2}$ & Obs. & Exp. & $\mathrm{x}^{2}$ & Obs. & Exp. & $x^{2}$ \\
\hline $\begin{array}{l}5 \\
6 \\
7 \\
8\end{array}$ & $\begin{array}{l}8 \\
4 \\
3 \\
1\end{array}$ & $\begin{array}{l}4.00 \\
4.00 \\
4.00 \\
4.00\end{array}$ & $\begin{array}{l}4.00 \\
0.00 \\
0.25 \\
2.25\end{array}$ & $\begin{array}{l}1 \\
2 \\
1 \\
0\end{array}$ & $\begin{array}{l}1.00 \\
1.00 \\
1.00 \\
1.00\end{array}$ & $\begin{array}{l}0.00 \\
1.00 \\
0.00 \\
1.00\end{array}$ & $\begin{array}{l}0 \\
0 \\
1 \\
2\end{array}$ & $\begin{array}{l}0.75 \\
0.75 \\
0.75 \\
0.75\end{array}$ & $\begin{array}{l}0.75 \\
0.75 \\
0.08 \\
2.08\end{array}$ & $\begin{array}{l}0 \\
0 \\
0 \\
0\end{array}$ & $\begin{array}{l}0.00 \\
0.00 \\
0.00 \\
0.00\end{array}$ & $\begin{array}{l}0.00 \\
0.00 \\
0.00 \\
0.00\end{array}$ \\
\hline Totals & 16 & & 6.50 & 4 & & 2.00 & 3 & & 3.66 & 0 & & 0.00 \\
\hline $\begin{array}{r}5 \\
6 \\
7 \\
8 \\
9 \\
10 \\
11 \\
12\end{array}$ & $\begin{array}{r}4 \\
1 \\
6 \\
7 \\
10 \\
12 \\
4 \\
11\end{array}$ & $\begin{array}{l}6.88 \\
6.88 \\
6.88 \\
6.88 \\
6.88 \\
6.88 \\
6.88 \\
6.88\end{array}$ & $\begin{array}{l}1.21 \\
5.03 \\
0.11 \\
0.00 \\
1.41 \\
3.81 \\
1.21 \\
2.47\end{array}$ & $\begin{array}{l}1 \\
1 \\
1 \\
1 \\
3 \\
3 \\
1 \\
2\end{array}$ & $\begin{array}{l}1.63 \\
1.63 \\
1.63 \\
1.63 \\
1.63 \\
1.63 \\
1.63 \\
1.63\end{array}$ & $\begin{array}{l}0.24 \\
0.24 \\
0.24 \\
0.24 \\
1.15 \\
1.15 \\
0.24 \\
0.08\end{array}$ & $\begin{array}{l}2 \\
1 \\
0 \\
0 \\
0 \\
0 \\
0 \\
3\end{array}$ & $\begin{array}{l}0.75 \\
0.75 \\
0.75 \\
0.75 \\
0.75 \\
0.75 \\
0.75 \\
0.75\end{array}$ & $\begin{array}{l}2.08 \\
0.08 \\
0.75 \\
0.75 \\
0.75 \\
0.75 \\
0.75 \\
6.75\end{array}$ & $\begin{array}{l}0 \\
0 \\
0 \\
0 \\
0 \\
0 \\
0 \\
1\end{array}$ & $\begin{array}{l}0.13 \\
0.13 \\
0.13 \\
0.13 \\
0.13 \\
0.13 \\
0.13 \\
0.13\end{array}$ & $\begin{array}{l}0.13 \\
0.13 \\
0.13 \\
0.13 \\
0.13 \\
0.13 \\
0.13 \\
5.82\end{array}$ \\
\hline Totals & 55 & & 15.25 & 13 & & 3.58 & 6 & & 12.66 & 1 & & 6.73 \\
\hline $\begin{array}{r}9 \\
10 \\
11 \\
12 \\
13 \\
14\end{array}$ & $\begin{array}{r}14 \\
4 \\
14 \\
8 \\
16 \\
11\end{array}$ & $\begin{array}{l}11.17 \\
11.17 \\
11.17 \\
11.17 \\
11.17 \\
11.17\end{array}$ & $\begin{array}{l}0.72 \\
4.60 \\
0.72 \\
0.90 \\
2.09 \\
0.00\end{array}$ & $\begin{array}{l}3 \\
3 \\
0 \\
3 \\
4 \\
3\end{array}$ & $\begin{array}{l}2.67 \\
2.67 \\
2.67 \\
2.67 \\
2.67 \\
2.67\end{array}$ & $\begin{array}{l}0.04 \\
0.04 \\
2.67 \\
0.04 \\
0.66 \\
0.04\end{array}$ & $\begin{array}{l}1 \\
2 \\
0 \\
1 \\
3 \\
2\end{array}$ & $\begin{array}{l}1.50 \\
1.50 \\
1.50 \\
1.50 \\
1.50 \\
1.50\end{array}$ & $\begin{array}{l}0.17 \\
0.17 \\
1.50 \\
0.17 \\
1.50 \\
1.17\end{array}$ & $\begin{array}{l}0 \\
1 \\
0 \\
1 \\
1 \\
1\end{array}$ & $\begin{array}{l}0.67 \\
0.67 \\
0.67 \\
0.67 \\
0.67 \\
0.67\end{array}$ & $\begin{array}{l}0.67 \\
0.16 \\
0.67 \\
0.16 \\
0.16 \\
0.16\end{array}$ \\
\hline Totals & 67 & & 9.03 & 16 & & 3.49 & 9 & & 3.68 & 4 & & 1.98 \\
\hline
\end{tabular}


$\Lambda$ Inter

\begin{tabular}{|c|c|c|c|c|c|c|c|c|c|c|c|c|}
\hline \multirow{3}{*}{$\begin{array}{c}\text { Gate } \\
\text { No. }\end{array}$} & \multicolumn{11}{|c|}{ Days } & \\
\hline & \multicolumn{3}{|c|}{$1-4$} & \multicolumn{3}{|c|}{$5-8$} & \multicolumn{3}{|c|}{$9-12$} & \multicolumn{3}{|c|}{$13-16$} \\
\hline & Obs. & Exp. $\underline{b}$ & $x^{2}$ & Obs. & Exp. & $x^{2}$ & Obs. & Exp. & $x^{2}$ & Obs. & Exp. & $x^{2}$ \\
\hline $\begin{array}{l}5 \\
6 \\
7 \\
8\end{array}$ & $\begin{array}{l}0 \\
0 \\
0 \\
0\end{array}$ & $\begin{array}{l}0.00 \\
0.00 \\
0.00 \\
0.00\end{array}$ & $\begin{array}{l}0.00 \\
0.00 \\
0.00 \\
0.00\end{array}$ & $\begin{array}{l}1 \\
0 \\
0 \\
0\end{array}$ & $\begin{array}{l}0.25 \\
0.25 \\
0.25 \\
0.25\end{array}$ & $\begin{array}{l}2.25 \\
0.25 \\
0.25 \\
0.25\end{array}$ & $\begin{array}{l}1 \\
2 \\
0 \\
3\end{array}$ & $\begin{array}{l}1.50 \\
1.50 \\
1.50 \\
1.50\end{array}$ & $\begin{array}{l}0.17 \\
0.17 \\
1.50 \\
1.50\end{array}$ & $\begin{array}{l}0 \\
5 \\
2 \\
7\end{array}$ & $\begin{array}{l}3.50 \\
3.50 \\
3.50 \\
3.50\end{array}$ & $\begin{array}{l}3.50 \\
0.64 \\
0.64 \\
3.50\end{array}$ \\
\hline Totals & 0 & & 0.00 & 1 & & 3.00 & 6 & & 3.34 & 14 & & 8.28 \\
\hline $\begin{array}{r}5 \\
6 \\
7 \\
8 \\
9 \\
10 \\
11 \\
12\end{array}$ & $\begin{array}{l}0 \\
0 \\
0 \\
0 \\
0 \\
0 \\
0 \\
0\end{array}$ & $\begin{array}{l}0.00 \\
0.00 \\
0.00 \\
0.00 \\
0.00 \\
0.00 \\
0.00 \\
0.00\end{array}$ & $\begin{array}{l}0.00 \\
0.00 \\
0.00 \\
0.00 \\
0.00 \\
0.00 \\
0.00 \\
0.00\end{array}$ & $\begin{array}{l}0 \\
0 \\
0 \\
1 \\
1 \\
1 \\
1 \\
3\end{array}$ & $\begin{array}{l}0.88 \\
0.88 \\
0.88 \\
0.88 \\
0.88 \\
0.88 \\
0.88 \\
0.88\end{array}$ & $\begin{array}{l}0.88 \\
0.88 \\
0.88 \\
0.88 \\
0.02 \\
0.02 \\
0.02 \\
5.11\end{array}$ & $\begin{array}{l}3 \\
1 \\
1 \\
2 \\
0 \\
1 \\
2 \\
2\end{array}$ & $\begin{array}{l}1.50 \\
1.50 \\
1.50 \\
1.50 \\
1.50 \\
1.50 \\
1.50 \\
1.50\end{array}$ & $\begin{array}{l}1.50 \\
0.17 \\
0.17 \\
0.17 \\
1.50 \\
0.17 \\
0.17 \\
0.17\end{array}$ & $\begin{array}{l}2 \\
3 \\
2 \\
5 \\
1 \\
5 \\
2 \\
3\end{array}$ & $\begin{array}{l}2.88 \\
2.88 \\
2.88 \\
2.88 \\
2.88 \\
2.88 \\
2.88 \\
2.88\end{array}$ & $\begin{array}{l}0.27 \\
0.01 \\
0.27 \\
1.56 \\
1.23 \\
1.56 \\
0.27 \\
0.01\end{array}$ \\
\hline Totals & 0 & & 0.00 & 7 & & 7.81 & 12 & & 4.02 & 23 & & 5.18 \\
\hline $\begin{array}{r}9 \\
10 \\
11 \\
12 \\
13 \\
14\end{array}$ & $\begin{array}{l}0 \\
0 \\
0 \\
0 \\
1 \\
2\end{array}$ & $\begin{array}{l}0.50 \\
0.50 \\
0.50 \\
0.50 \\
0.50 \\
0.50\end{array}$ & $\begin{array}{l}0.50 \\
0.50 \\
0.50 \\
0.50 \\
0.50 \\
4.50\end{array}$ & $\begin{array}{l}1 \\
0 \\
5 \\
0 \\
2 \\
2\end{array}$ & $\begin{array}{l}1.67 \\
1.67 \\
1.67 \\
1.67 \\
1.67 \\
1.67\end{array}$ & $\begin{array}{l}0.27 \\
1.67 \\
6.64 \\
1.67 \\
0.07 \\
0.07\end{array}$ & $\begin{array}{l}2 \\
1 \\
3 \\
3 \\
3 \\
1\end{array}$ & $\begin{array}{l}2.17 \\
2.17 \\
2.17 \\
2.17 \\
2.17 \\
2.17\end{array}$ & $\begin{array}{l}0.01 \\
0.63 \\
0.32 \\
0.32 \\
0.32 \\
0.63\end{array}$ & $\begin{array}{l}1 \\
1 \\
2 \\
2 \\
3 \\
5\end{array}$ & $\begin{array}{l}2.33 \\
2.33 \\
2.33 \\
2.33 \\
2.33 \\
2.33\end{array}$ & $\begin{array}{l}0.76 \\
0.76 \\
0.05 \\
0.05 \\
0.19 \\
3.06\end{array}$ \\
\hline Totals & 3 & & 7.00 & 10 & & 10.39 & 13 & & 2.23 & 14 & & 4.87 \\
\hline
\end{tabular}




\section{Inter}

\begin{tabular}{|c|c|c|c|c|c|c|c|c|c|c|c|c|}
\hline \multirow{3}{*}{$\begin{array}{l}\text { Gate } \\
\text { No. }\end{array}$} & \multicolumn{9}{|c|}{ Days } & & & \\
\hline & \multicolumn{3}{|c|}{$1-4$} & \multicolumn{3}{|c|}{$5-8$} & \multicolumn{3}{|c|}{$9-12$} & \multicolumn{3}{|c|}{$13-16$} \\
\hline & Obs. & $\operatorname{Exp}_{.} \underline{b}$ & $\mathrm{x}^{2}$ & Obs. & Exp. & $\mathrm{x}^{2}$ & Obs. & Exp. & $\mathrm{x}^{2}$ & Obs. & Exp. & $x^{2}$ \\
\hline $\begin{array}{l}5 \\
6 \\
7 \\
8\end{array}$ & $\begin{array}{l}3 \\
3 \\
1 \\
2\end{array}$ & $\begin{array}{l}2.25 \\
2.25 \\
2.25 \\
2.25\end{array}$ & $\begin{array}{l}0.25 \\
0.25 \\
0.69 \\
0.03\end{array}$ & $\begin{array}{r}11 \\
5 \\
2 \\
2\end{array}$ & $\begin{array}{l}5.00 \\
5.00 \\
5.00 \\
5.00\end{array}$ & $\begin{array}{l}7.20 \\
0.00 \\
1.80 \\
1.80\end{array}$ & $\begin{array}{l}6 \\
4 \\
0 \\
1\end{array}$ & $\begin{array}{l}2.75 \\
2.75 \\
2.75 \\
2.75\end{array}$ & $\begin{array}{l}3.84 \\
0.57 \\
2.75 \\
1.11\end{array}$ & $\begin{array}{l}0 \\
2 \\
4 \\
0\end{array}$ & $\begin{array}{l}1.50 \\
1.50 \\
1.50 \\
1.50\end{array}$ & $\begin{array}{l}1.50 \\
0.17 \\
4.17 \\
1.50\end{array}$ \\
\hline Totals & 9 & & 1.22 & 20 & & 10.80 & 11 & & 8.27 & 6 & & 7.34 \\
\hline $\begin{array}{r}5 \\
6 \\
7 \\
8 \\
9 \\
10 \\
11 \\
12\end{array}$ & $\begin{array}{r}5 \\
1 \\
5 \\
1 \\
3 \\
12 \\
2 \\
19\end{array}$ & $\begin{array}{l}6.00 \\
6.00 \\
6.00 \\
6.00 \\
6.00 \\
6.00 \\
6.00 \\
6.00\end{array}$ & $\begin{array}{r}0.17 \\
4.17 \\
0.17 \\
4.17 \\
1.50 \\
6.00 \\
2.67 \\
28.17\end{array}$ & $\begin{array}{r}4 \\
6 \\
8 \\
2 \\
34 \\
8 \\
5 \\
20\end{array}$ & $\begin{array}{l}10.88 \\
10.88 \\
10.88 \\
10.88 \\
10.88 \\
10.88 \\
10.88 \\
10.88\end{array}$ & $\begin{array}{r}4.35 \\
2.19 \\
0.76 \\
7.25 \\
49.13 \\
0.76 \\
3.18 \\
7.65\end{array}$ & $\begin{array}{r}0 \\
2 \\
4 \\
5 \\
72 \\
33 \\
4 \\
10\end{array}$ & $\begin{array}{l}16.25 \\
16.25 \\
16.25 \\
16.25 \\
16.25 \\
16.25 \\
16.25 \\
16.25\end{array}$ & $\begin{array}{r}16.25 \\
12.50 \\
9.23 \\
7.79 \\
191.27 \\
17.27 \\
9.23 \\
2.40\end{array}$ & $\begin{array}{l}2 \\
1 \\
0 \\
3 \\
5 \\
8 \\
0 \\
5\end{array}$ & $\begin{array}{l}3.00 \\
3.00 \\
3.00 \\
3.00 \\
3.00 \\
3.00 \\
3.00 \\
3.00\end{array}$ & $\begin{array}{l}0.33 \\
1.33 \\
3.00 \\
0.00 \\
1.33 \\
8.33 \\
3.00 \\
1.33\end{array}$ \\
\hline Totals & 48 & & 47.02 & 87 & & 75.27 & 130 & & 265.94 & 24 & & 18.65 \\
\hline $\begin{array}{l}9 \\
10 \\
11 \\
12 \\
13 \\
14\end{array}$ & $\begin{array}{r}13 \\
4 \\
5 \\
17 \\
20 \\
23\end{array}$ & $\begin{array}{l}13.67 \\
13.67 \\
13.67 \\
13.67 \\
13.67 \\
13.67\end{array}$ & $\begin{array}{l}0.03 \\
6.84 \\
5.50 \\
0.81 \\
2.93 \\
6.37\end{array}$ & $\begin{array}{l}17 \\
10 \\
16 \\
23 \\
22 \\
26\end{array}$ & $\begin{array}{l}19.00 \\
19.00 \\
19.00 \\
19.00 \\
19.00 \\
19.00\end{array}$ & $\begin{array}{l}0.21 \\
4.26 \\
0.47 \\
0.84 \\
0.47 \\
2.58\end{array}$ & $\begin{array}{r}9 \\
5 \\
11 \\
94 \\
58 \\
37\end{array}$ & $\begin{array}{l}35.66 \\
35.66 \\
35.66 \\
35.66 \\
35.66 \\
35.66\end{array}$ & $\begin{array}{r}19.93 \\
26.36 \\
17.05 \\
95.44 \\
14.00 \\
0.05\end{array}$ & $\begin{array}{r}3 \\
1 \\
4 \\
11 \\
9 \\
10\end{array}$ & $\begin{array}{l}6.33 \\
6.33 \\
6.33 \\
6.33 \\
6.33 \\
6.33\end{array}$ & $\begin{array}{l}1.75 \\
4.49 \\
0.86 \\
3.45 \\
1.13 \\
2.13\end{array}$ \\
\hline Totals & 82 & & 22.48 & 114 & & 8.83 & 214 & & 186.83 & 38 & & 13.81 \\
\hline
\end{tabular}


SPACE USA GE BY THE SMALL MAMMAL,

DIPODOMYS MICROPS (MERRIAM)

Barney W. Cornaby

Department of Zoology

M. S. Degree, August 1971

\begin{abstract}
Movements of kangaroo rats, Dipodomys microps (Merriam), were assessed as a function of patterns of gate usages in an activity arena and evaluated for possible deviation from randomness with the chi-square goodness of fit test. The animals utilized space nonrandomly whether food was randomly dispersed or aggregated. Their preferential usage of space suggested that when the circular home range technique is used to estimate probable interaction among small mammals, the probability of being a given distance as well as the probability of being a given direction from the center of activity should be considered. This distinction will increa se the fidelity of activity models that are used in under standing epidemiology of rodent diseases, gene flow, and other fundamental aspects of small mammal ecology.
\end{abstract}




\section{VITA}

$\checkmark$ 